\title{
Dioxygen Activation by Laccases: Green Chemistry for Fine Chemical Synthesis
}

\author{
Cynthia Romero-Guido *, Antonino Baez * (1) and Eduardo Torres * (1) \\ Instituto de Ciencias, Benemérita Universidad Autónoma de Puebla, Puebla 72570, Mexico \\ * Correspondence: cynthia.romerogui@correo.buap.mx (C.R.-G.); antonino.baez@correo.buap.mx (A.B.); \\ eduardo.torres@correo.buap.mx (E.T.); Tel.: +52-222-229-5500 (C.R.-G. \& A.B. \& E.T.)
}

Received: 30 April 2018; Accepted: 23 May 2018; Published: 24 May 2018

\begin{abstract}
Laccases are enzymes with attractive features for the synthesis of fine chemicals. The friendly reaction conditions of laccases and their high conversion and selectivity make them particularly suitable for green methods of synthesis. In addition, laccases are enzymes with broad substrate variability, ease of production, and no need of cofactors or aggressive oxidizing agents. Among molecules oxidized by laccases are polycyclic aromatic hydrocarbons, azo dyes, pesticides, phenols, and pharmaceuticals. This article reviews the laccase-mediated oxidation of fine chemicals for the production of biologically active compounds. The main aspects of the enzymatic oxidation are summarized; potentials and limitations are identified and proposals to develop more robust catalysts are analyzed.
\end{abstract}

Keywords: enzymatic oxidation; enzymatic dioxygen activation; laccases; pharmaceutical synthesis

\section{Introduction}

The production of fine chemicals (intermediates and final products) is of interest for pharmaceutical industry. A hallmark of current drug-production processes is the large quantities of organic solvents and energy required for the synthesis and purification. Besides, synthetic chemistry for industrial applications produces an excessive amount of wastes (toxic by-products and solvents), which could be up to $85 \%$ solvent by mass product [1,2]. Since the pharmaceutical sector produces over 1000 tons of product per year, with $25-100 \mathrm{~kg}$ waste $/ \mathrm{kg}$ product $[3,4]$, it is evident that there is a necessity for more sustainable processes production. Against this background, green production processes with high environmental acceptability and economic feasibility are getting particular attention in most developed countries. Thus, the European Commission and US Environmental Protection Agency award different prizes encouraging industries to develop novel manufacturing processes considering environmental factors, energy efficiency, and use of renewable feedstocks $[5,6]$.

Therefore, green methodologies are needed to reduce the environmental impact and the economic cost of the whole processes. Biocatalysts offer sustainable technological alternatives to the processes already applied to industry, particularly in the pharmaceutical, agrochemical, and food fields $[4,7,8]$. The advantages of biocatalytic processes arise from the ability of enzymes to catalyze complex reactions at mild conditions and to generate few or no side-products. Other advantages over traditional organic synthesis are the usage of water as a solvent, specific regionand stereo-selectivity, no need for functional group protection, and deprotection steps $[9,10]$. Being the high chemoselectivity, regioselectivity, and stereoselectivity the most outstanding traits of biocatalysis [11,12]. In addition to catalysis in aqueous environments, enzymes can carry out esterification, biocatalytic enantioselective sulfur oxidation, and hydrogenation in different solvent mixtures; e.g., choline chloride/glycerol/water, liquid polymers, and supercritical $\mathrm{CO}_{2}$ [1]. These abilities usually lead to energy savings, low operating costs, increased safety and minimal pollutant 
emissions. Particularly, oxidation reactions are essential in several industries from bulk to fine chemical production. To this end, application of laccases for oxidation processes is the most interesting due to gentle conditions applied for dioxygen activation. Laccases are blue multi-copper oxidases with four copper ions coordinated at the active site (Figure 1).

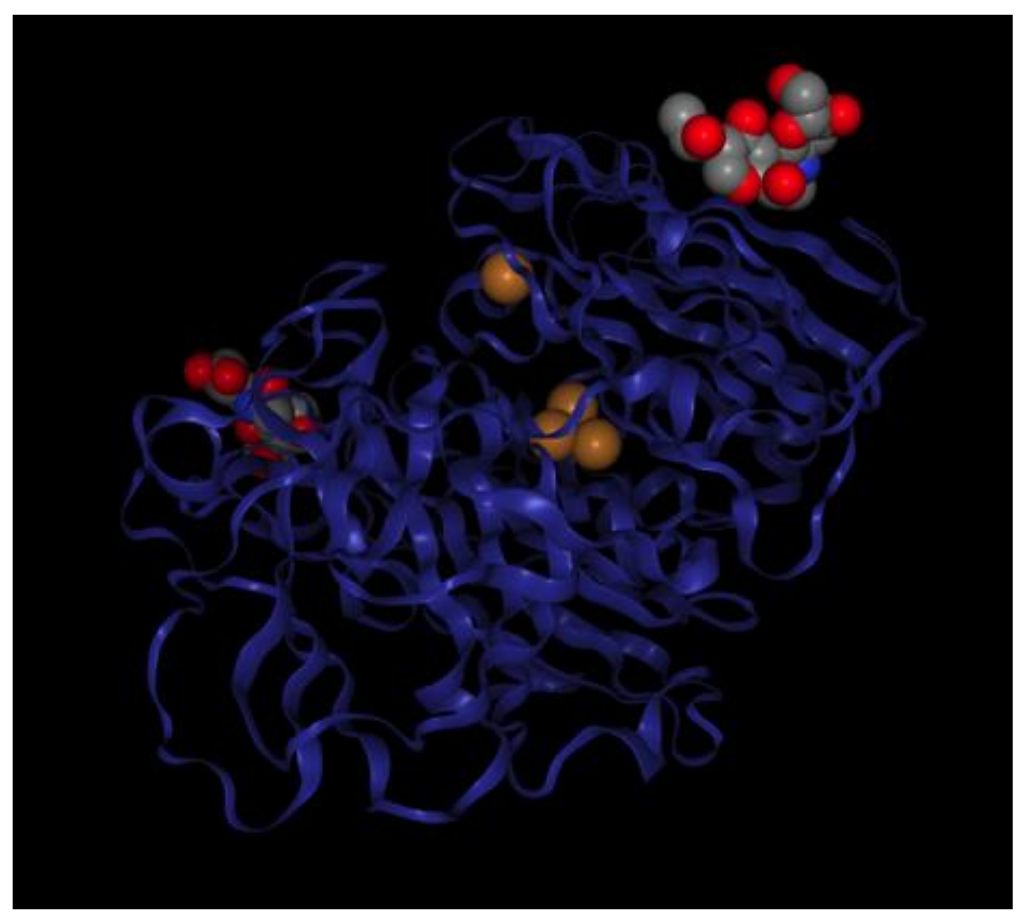

Figure 1. Representation of laccase structure from Trametes trogii. Orange spheres refer to copper atoms, red and grey spheres to carbohydrates moieties of the enzyme. Figure prepared using the on-line viewer for proteins "NGL Viewer" [13,14], using the data from [15]. Substrate binding site (T1 copper) is shown at the enzyme surface while T2 and T3 copper ions (oxygen reduction site) are in the interior of the molecule.

The copper ions are coordinated to form one Type 1 copper site (one copper ion), where the substrate is oxidized at the enzyme surface (substrate binding site), one Type 2 site (one copper ion) and one Type 3 site (two copper ions) in the inner space of the enzyme. The type 2 and 3 sites form the trinuclear oxygen binding site [16]. Substrates are oxidized at the T1 copper site, which rapidly transfers electrons to the trinuclear cluster (T2 and T3 coppers), where dioxygen is then reduced to water in two sequential steps (Figure 2) [17].

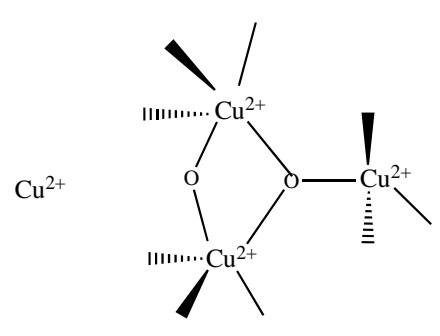

T1

T3

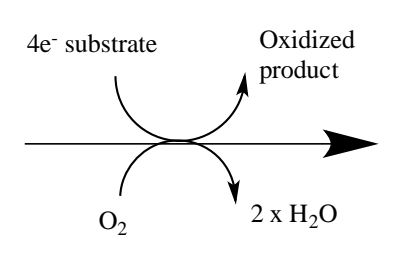

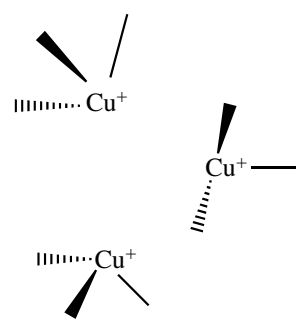

T3 T2

Figure 2. A simplified representation of the general reaction mechanism catalyzed by laccase enzymes. Adapted from [17] with permission. 
Laccases catalyze the oxidation of phenols, amines and some of their derivatives, as well as inorganic ions coupled to the reduction of molecular dioxygen to water $[18,19]$. In addition, the laccase-oxidation assisted by low molecular mediators has been applied to numerous processes such as aromatic dyes, polycyclic aromatic hydrocarbons (PAH), pesticides, and pharmaceuticals [20,21]. Several reviews on the biochemistry, structure, kinetics, and applications of laccases have been published [22-26]. Unlike previous reports, the aim of this review is to highlight the potential applications of laccases for the synthesis of pharmaceutical products, wherein high selectivity and mild reaction conditions are necessary, especially where dioxygen activation is required. The potentials and limitations of laccases for industrial application are examined in the context of fermentation production, synthesis reactions, and feature improvement opportunities.

\section{Laccases for Pharmaceutical Green Chemistry}

Traditional pharmaceutical industry involves time-consuming, multi-step reaction, high cost and hazardous methods for the synthesis of drugs. Since the 90s when the Green Chemistry was born, this modern area has revolutionized the way to synthesize organic compounds. Since then, green chemistry has been looking for sustainable synthesis processes base on 12 principles stipulated by Paul Anastas and John Warner [27]. In the biopharma sector, unlike the traditional pharmaceutical industry, green chemistry focuses on the design of facile, eco-friendly, cost-efficient, sustainable, and high yielding methods for the synthesis of new drugs that are safe for human health and environment. For the synthesis of anticancer molecules, for example, green methods were developed based on physicochemical procedures as microwave irradiation, ultrasonic irradiation, Claisen-Schmidt condensation, green solvents, and high temperatures (from 80 to $130^{\circ} \mathrm{C}$ ) to obtain product yields of $70 \%$ and $96 \%$ [28]. However, the green physicochemical procedures still require special equipment, multiple chemicals consumption, and large quantities of energy. Enzyme-catalyzed biosynthesis could be a green method and, moreover, reduces energy and chemicals consumption. Laccases (EC1.10.32) are enzymes that have been studied to develop pharmaceutical biosynthesis methods. They belong to a family of extracellular, multi-copper containing oxidoreductases present in plants, fungi, and the bacterium Azospirillum lipoferum. Laccases catalyze the oxidation of a vast range of phenolic substrates presenting low redox potentials without the need of a co-factor, but they are also able to catalyze non-phenolic substrates in a reaction dependent on the presence of a primary laccase-substrate, as for example the artificial laccase substrate ABTS [2,2'-azinobis(3-ethylenthiazoline-6-sulphonate)] which acts as an oxidation mediator. The reaction catalyzed by laccases reduces molecular oxygen and releases water as the only by-product [29], therefore reactions catalyzed by these enzymes are free of toxic oxidants and toxic by-products. The advantage of laccases for the biosynthesis of pharmaceuticals is their ability to catalyze one-pot synthesis under mild conditions, which imply room temperature, aqueous solvent (solvent-free less toxic), high $\mathrm{pH}$ range from 3 to 7 , aerial molecular oxygen that can be supplied by just open vessel, bubbling air or by stirring, and short reaction times. The synthesis of new pharmaceutical compounds by laccase oxidation under mild conditions with no hazardous or toxic by-products and high yields (37 to 99\%) have been reported. Moreover, in vitro assays of some biosynthesized pharmaceutical compounds showed new biological activities. The most recent pharmaceutical compounds synthesized by laccases under mild conditions are listed in Table 1.

Table 1. Pharmaceutical compounds synthesized by laccases under mild reaction conditions.

\begin{tabular}{|c|c|c|c|}
\hline Product & Laccase Source & Reaction Conditions and Results & Reference \\
\hline \multicolumn{4}{|l|}{ Anticancer compounds } \\
\hline \multirow[t]{2}{*}{ * Amino-naphtoquinones } & $\begin{array}{l}\text { Commercial Novozyme 51003, } \\
\text { laccase from Myceliophthora } \\
\text { thermophile, Novozymes }\end{array}$ & $\begin{array}{l}\text { 1.0 M succinate-lactate buffer } \mathrm{pH} 4.5 ; 35^{\circ} \mathrm{C} ; 2220 \text { U laccase; } \\
1.2 \mathrm{mmol} \text { amine and } 0.6 \mathrm{mmol} 1,4 \text {-dihydroxy-2-naphthoic } \\
\text { acid; } 1 \mathrm{~mL} \text { DMF as a co-solvent. } 48 \mathrm{~h}, 77 \% \text { yield }\end{array}$ & [30] \\
\hline & & $\begin{array}{l}\text { 0.01 M sodium phosphate buffer } \mathrm{pH} 6.0 ; 40^{\circ} \mathrm{C} \text {; stirring; } \\
2775 \mathrm{U} \text { laccase; } 1.2 \mathrm{mmol} \text { amine and } 0.6 \mathrm{mmol} \\
\text { 1,4-dihydroxy-2-naphthoic acid; DMF. } 48 \mathrm{~h}, 85 \% \text { yield }\end{array}$ & [30] \\
\hline
\end{tabular}


Table 1. Cont

\begin{tabular}{|c|c|c|c|}
\hline Product & Laccase Source & Reaction Conditions and Results & Reference \\
\hline \multirow[t]{2}{*}{ 1,4-Naphthoquinone-2,3-bis-sulfides } & $\begin{array}{l}\text { Commercial Novozyme } 51003 \text {, } \\
\text { laccase from Myceliophthora } \\
\text { thermophile, Novozymes }\end{array}$ & $\begin{array}{l}1 \mathrm{M} \text { succinate-lactate buffer } \mathrm{pH} 4.5 ; 35^{\circ} \mathrm{C} \text {; air by stirring; } \\
3885 \mathrm{U} \text { laccase; } 0.6 \mathrm{mmol} 1,4 \text {-naphthohydroquinone and } \\
1.8 \mathrm{mmol} \text { thiol. } 48 \mathrm{~h}, 69 \% \text { yield }\end{array}$ & [31] \\
\hline & & $\begin{array}{l}0.1 \mathrm{M} \text { potassium phosphate buffer } \mathrm{pH} 7.15 \text {; air by stirring; } \\
6660 \mathrm{U} \text { laccase; } 0.6 \mathrm{mmol} 1,4 \text { naphthohydroquinone and } \\
1.8 \mathrm{mmol} \text { thiol. } 48 \mathrm{~h}, 56 \% \text { yield }\end{array}$ & [31] \\
\hline $\begin{array}{l}\text { *5,6-Dihydroxylated benzo }[b] \text { furans } \\
\text { and catechol derivatives }\end{array}$ & $\begin{array}{l}\text { Commercial Suberase, laccase } \\
\text { from Myceliophthora } \\
\text { thermophila, Novozymes }\end{array}$ & $\begin{array}{l}0.1 \mathrm{M} \text { phosphate buffer pH7.15; R.T.; air; 10,757.8 PCU/mL } \\
\text { laccase; } 2.0 \mathrm{mmol} \text { catechol and } 2.0 \mathrm{mmol} \text { 1,3-dicarbonyl. } 24 \mathrm{~h} \text {, } \\
98 \% \text { yield }\end{array}$ & [32] \\
\hline * Coumestans derivatives & $\begin{array}{l}\text { Commercial Suberase, laccase } \\
\text { from Myceliophthora } \\
\text { thermophila, Novozymes }\end{array}$ & $\begin{array}{l}\text { 0.1 M Phosphate buffer pH 7.15; R.T.; air; } 10,757.8 \mathrm{PCU} / \mathrm{mL} \\
\text { laccase; } 2.0 \mathrm{mM} \text { catechols and } 2.0 \mathrm{mM} \text { coumarins. } 24 \mathrm{~h} \text {, } \\
86 \% \text { yield }\end{array}$ & [33] \\
\hline \multirow[t]{2}{*}{$\begin{array}{l}\text { * Pyrimido-benzothiazoles and } \\
\text { catechol thioeters }\end{array}$} & $\begin{array}{l}\text { Commercial laccase from } \\
\text { Agaricus bisporus, ASA } \\
\text { Spezialenzyme }\end{array}$ & $\begin{array}{l}0.2 \mathrm{M} \text { phosphate buffer pH } 6.0 / 10 \% \text { ethanol; R.T.; air; } 12 \mathrm{U} \\
\text { laccase; } 0.58 \mathrm{mmol} \text { catechol and } 0.5 \mathrm{mmol} \\
\text { 2,3-dihydro-2-thioxopyrimidin- } 4(1 \mathrm{H}) \text {-ones. } 14 \mathrm{~h}, 97 \% \text { yield }\end{array}$ & [34] \\
\hline & & $\begin{array}{l}0.2 \mathrm{M} \text { phosphate buffer } \mathrm{pH} \text { 6.0/10\% ethanol; R.T.; air; } 12 \mathrm{U} \\
\text { laccase; } 0.29 \text { mmol catechol and } 0.25 \mathrm{mmol} \\
\text { 2,3-dihydro-2-thioxopyrimidin- } 4(1 \mathrm{H}) \text {-ones. } 14 \mathrm{~h} \text {, } 95 \% \text { yield }\end{array}$ & [34] \\
\hline \multicolumn{4}{|l|}{ Antioxidant compounds } \\
\hline * Catechin polymers & $\begin{array}{l}\text { Commercial laccase from } \\
\text { Trametes versicolor, Sigma } \\
\text { Aldrich, conjugated with gum } \\
\text { Arabic }\end{array}$ & $\begin{array}{l}20 \mathrm{mM} \text { sodium citrate buffer } \mathrm{pH} 5.0 / \text { methanol in a ratio of } \\
\text { 1.0:0.6; R.T.; } 2300 \mathrm{U} / \mathrm{mg} \text { gum Arabic conjugated laccase; } \\
5 \mathrm{mmol} \text { catechin. } 0.5 \mathrm{~h}\end{array}$ & [35] \\
\hline * Polyrutin & $\begin{array}{l}\text { Commercial laccase from } \\
\text { Trametes versicolor. }\end{array}$ & $\begin{array}{l}\text { Methanol/water }(30: 70 \mathrm{v} / \mathrm{v}) ; 20^{\circ} \mathrm{C} \text {; air by stirring; } 3 \mathrm{U} / \mathrm{mL} \\
\text { laccase; } 50 \mathrm{~g} / \mathrm{L} \text { rutin. } 24 \mathrm{~h}\end{array}$ & [36] \\
\hline * Polyesculin & $\begin{array}{l}\text { Commercial laccase from } \\
\text { Trametes versicolor }\end{array}$ & $\begin{array}{l}\text { Methanol/water }(30: 70 \mathrm{v} / \mathrm{v}) ; 20^{\circ} \mathrm{C} \text {; air by stirring; } 3 \mathrm{U} / \mathrm{mL} \\
\text { laccase; } 50 \mathrm{~g} / \mathrm{L} \text { esculin. } 72 \mathrm{~h}\end{array}$ & [36] \\
\hline * Catechin polymers & $\begin{array}{l}\text { Commercial laccase from } \\
\text { Trametes versicolor (2020), ASA } \\
\text { Chemicals }\end{array}$ & $\begin{array}{l}0.1 \mathrm{M} \text { acetate buffer pH } 5.0 \text { with } 5 \%(v / v) \text { of the natural deep } \\
\text { eutectic solvents Betaine-Mannose (mole ratio } 5: 2), 30^{\circ} \mathrm{C} \text {, } \\
\text { bubbling air; } 125 \mathrm{U} \text { laccase, } 17.23 \mathrm{mmol} \text { catechin }(5 \mathrm{mg} / \mathrm{mL}) \text {. } \\
1 \mathrm{~h}, 83 \% \text { yield }\end{array}$ & [37] \\
\hline Catechol thioeters & $\begin{array}{l}\text { Non-commercial laccase from } \\
\text { Agaricus bisporus }\end{array}$ & $\begin{array}{l}0.2 \mathrm{M} \text { Phosphate buffer } \mathrm{pH} \text { 6.0/Methanol 10\%; R.T.; air; } 150 \mathrm{U} \\
\text { laccase; } 1.25 \text { mmol catechol and } 1 \mathrm{mmol} \\
\text { 2-mercaptobenzoxazole (thioeter). } 16 \mathrm{~h}, 95 \% \text { yield }\end{array}$ & [38] \\
\hline \multicolumn{4}{|l|}{ Antimicrobial compounds } \\
\hline$*$ B-lactam antibiotics & $\begin{array}{l}\text { Commercial laccase from } \\
\text { Myceliophthora thermophila, } \\
\text { Novozymes and commercial } \\
\text { laccase from Trametes sp., ASA } \\
\text { Spezialenzyme }\end{array}$ & $\begin{array}{l}\text { Citrate-phosphate buffer ( } 18 \mathrm{mM} \text { citrate, } 165 \mathrm{mM} \text { phosphate) } \\
\text { pH 7.0; R.T.; air by agitation; } 10 \mathrm{mM} \text { } \beta \text {-lactams and } 3 \mathrm{mM} \\
\text { 2,5-dihydroxyphenylacetic acid. } 4 \mathrm{~h}, 60 \% \text { yield }\end{array}$ & [39] \\
\hline Pyrimido-benzothiazole derivatives & $\begin{array}{l}\text { Commercial laccase from } \\
\text { Agaricus bisporus, ASA } \\
\text { Spezialenzyme GmbH, } \\
\text { Wolfenbüttel }\end{array}$ & $\begin{array}{l}0.2 \mathrm{M} \text { phosphate buffer } \mathrm{pH} 6.0 / \text { methanol }(85: 15, v / v) ; 22{ }^{\circ} \mathrm{C}, \\
\text { air; } 60 \mathrm{U} \text { laccase; } 0.63 \mathrm{mmol} \text { catechol and } 0.5 \mathrm{mmol} .15 \mathrm{~h} \\
\text { 1,2,3,4-tetrahydro-4-oxo-6-phenyl-2-thioxo-5-pyrimidinecarbonitrile. } \\
15 \mathrm{~h}, 95 \% \text { yield }\end{array}$ & {$[40]$} \\
\hline \multicolumn{4}{|l|}{ Antiglycation compounds } \\
\hline * Catechin polymers & $\begin{array}{l}\text { Commercial Denilite IIS, } \\
\text { laccase from Aspergillus oryzae, } \\
\text { Novozymes }\end{array}$ & $\begin{array}{l}0.1 \text { sodium acetate buffer } \mathrm{pH} 5.0 / \text { methanol 5\%; R.T.; stirring } \\
600 \mathrm{U} \text { laccase; } 1 \mathrm{~g}(+) \text {-Catechin hydrate. } 24 \mathrm{~h},>60 \% \text { yield }\end{array}$ & [41] \\
\hline \multicolumn{4}{|l|}{$\begin{array}{l}\text { New pharmacologically active } \\
\text { substances }\end{array}$} \\
\hline $\begin{array}{l}\text { 1,3,9-Trioxa-fluoren-4-one } \\
\text { derivatives }\end{array}$ & $\begin{array}{l}\text { Non-commercial laccase from } \\
\text { Pycnoporus cinnabarinus }\end{array}$ & $\begin{array}{l}1 \mathrm{M} \text { phosphate/citrate buffer } \mathrm{pH} 7.0 ; 5^{\circ} \mathrm{C} \text { the first } 2 \mathrm{~h} \text { before } \\
\text { increasing to R.T.; air by stirring; } 400 \mathrm{U} \text { laccase; } 1 \mathrm{mmol} \\
\text { Meldrum's acid and } 2 \mathrm{mmol} \text { catechol. } 12 \mathrm{~h}, 55 \% \text { yield }\end{array}$ & [42] \\
\hline \multicolumn{4}{|l|}{ Synthetic intermediates } \\
\hline \multirow[t]{2}{*}{ Benzylic nitriles } & $\begin{array}{l}\text { Commercial laccase from } \\
\text { Trametes villosa, Novo Nordisk }\end{array}$ & $\begin{array}{l}0.1 \mathrm{M} \text { sodium phosphate buffer } \mathrm{pH} 7.0 ; 60^{\circ} \mathrm{C} \text {, bubbled } \mathrm{O}_{2} \\
10 \mathrm{U} \text { laccase; } 1 \text { mmol benzoylacetronitrile and } 0.25 \mathrm{mmol} \\
\text { methoxyhydroquinone. } 24 \mathrm{~h}, 37 \% \text { yield }\end{array}$ & [43] \\
\hline & & $\begin{array}{l}0.1 \mathrm{M} \text { sodium phosphate buffer } \mathrm{pH} 7.0 ; 60^{\circ} \mathrm{C} \text {, bubbled } \mathrm{O}_{2} \\
100 \mathrm{U} \text { laccase; } 1 \text { mmol benzoylacetronitrile and } 0.25 \mathrm{mmol} \\
\text { substituted hydroquinone. } 24 \mathrm{~h}, 89 \% \text { yield }\end{array}$ & [43] \\
\hline Phenothiazones & $\begin{array}{l}\text { Commercial laccase } \\
\text { Not specified origin }\end{array}$ & $\begin{array}{l}0.1 \mathrm{M} \text { sodium acetate buffer pH 5.0/methanol } 10-15 \% \text {; R.T.; } \\
50 \mathrm{U} \text { laccase added after } 2 \mathrm{~h} ; 0.5 \mathrm{mmol} 2 \text {-aminothiophenol and } \\
0.625 \mathrm{mmol} \text { 1,4-quinone. } 6 \mathrm{~h}, 61 \% \text { yield }\end{array}$ & [44] \\
\hline $\begin{array}{l}\text { Ortho-dihydroxylated aromatic, } \\
\text { mono-aminated and di-aminated } \\
\text { compounds }\end{array}$ & $\begin{array}{l}\text { Non-commercial laccase from } \\
\text { Pycnoporus cinnabarinus. }\end{array}$ & $\begin{array}{l}20 \mathrm{mM} \text { sodium acetate buffer pH 5.0; R.T.; air by agitation; } \\
0.5 \mathrm{U} \text { laccase; } 1 \mathrm{mM} \text { or } 2 \mathrm{mM} \text { dihydroxylated compounds and } \\
1 \mathrm{mM} \text { or } 2 \mathrm{mM} \text { amines., } 44 \% \text { yield }\end{array}$ & [45] \\
\hline Sulphonyl benzenediols & $\begin{array}{l}\text { Commercial laccase from } \\
\text { Tramates versicolor. }\end{array}$ & $\begin{array}{l}\text { 0.1 M phosphate buffer } \mathrm{pH} \text { 5.0; R.T.; } \mathrm{O}_{2} ; 40 \mathrm{U} \text { laccase; } 1 \mathrm{mmol} \\
\text { sodium sulphinate and } 1 \mathrm{mmol} \text { benzenediols. } 18 \mathrm{~h},>99 \% \text { yield }\end{array}$ & [46] \\
\hline Quinoxalines & $\begin{array}{l}\text { Non-commercial laccase from } \\
\text { Ganoderma sp. rckk-02 }\end{array}$ & $\begin{array}{l}1 \mathrm{M} \text { phosphate/citrate buffer } \mathrm{pH} 7.0 ; 25^{\circ} \mathrm{C} ; 200 \mathrm{U} \text { laccase; } \\
N, N^{\prime} \text {-dimethylethylenediamine and } 1,2 \text {-dihydroxy benzene. } \\
10 \mathrm{~h}, 61 \% \text { yield }\end{array}$ & [47] \\
\hline
\end{tabular}

This table compiles the higher yields under the tested reaction conditions. $\left({ }^{*}\right)$ Proved activity. 


\subsection{Laccase-Catalyzed Pharmaceuticals}

Laccase-catalyzed reactions by green chemistry approaches have demonstrated to generate similar or higher product yields than conventional methods with the advantage of reducing hazardous waste. Some examples of pharmaceutical molecules synthesized by green chemistry methods applying laccases are discussed in this section. Specifications of reaction conditions can be consulted in Table 1. Some examples mentioned have been tested in vitro and/or in vivo and their positive activity make them attractive pharmaceuticals candidates. Details of the enzymatic mechanisms and structure-activity relationship of pharmaceutical compounds synthesized by laccases are fully described by Kudanga et al. [19].

\subsubsection{Laccase-Synthesized Molecules with Anticancer Activity}

The World Health Organization dictate that "cancer is a leading cause of death worldwide, accounting for 8.8 million deaths in 2015" [48]. The high incidence of cancer in the world and the emerging resistance of carcinogenic cells to the actual quimiotherapeutic pharmaceuticals leads to the urgent search of novel potent anticancer pharmaceuticals. Consequently, research has to be focused on designing novel anticancer drugs biosynthesis approaches. In the last years, laccases have been successfully used to synthesize compounds with potential application as anticancer drugs. Nevertheless, just a few laccase-synthesized compounds have been assayed for anticancer activity in vitro. Among pioneer works demonstrating the anticancer activity of laccase-synthesized compounds are those reported by Wellington and Kolesnikova [30], Wellington et al. [32], Qwebani-Onguleye et al. [33] and Abdel-Mohsen et al. [34].

(a) Aminonaphtoquinones. The synthesis of aminonaphtoquinones by nuclear monoamination of 1,4-naphtohydroquinone with primary aromatic amines catalyzed by the laccase Novozyme 51003 (Figure 3) was reported for the first time by Wellington and Kolesnikova [30]. The products were obtained with yields ranging from 32 to $77 \%$ at $\mathrm{pH} 4.5$ and 25 to $86 \%$ yield at $\mathrm{pH} 6.0$. The lower yield at $\mathrm{pH} 4.5$ could be due to the formation of a nitrile moiety that inhibited laccase activity. Increasing $\mathrm{pH}$ to 6.0 only increased the yield of one product, maybe due to a diminished catalytic activity of laccase. The anticancer activity of the synthesized products was determined by their growth inhibitory effect $\left(\mathrm{GI}_{50}\right)$, cytotoxic effect $\left(\mathrm{LC}_{50}\right)$ and cytostatic effect (TGI) against TK10 (renal), UACC62 (melanoma), MCF7 (breast) and HeLa (cervical) cancer cell lines. Aminonaphtoquinones exhibited different $\mathrm{GI}_{50}$, $\mathrm{LC}_{50}$ and TGI levels from inactive to potent against the cell lines compared to etoposide, an anticancer agent used as a positive control. Nevertheless, three of the aminonaphtoquinones exhibited potent cytostatic activity against the melanoma UACC62 cell line (7- to 8-fold higher than that of etoposide). It is noteworthy that those aminonaphtoquinones synthesized in the higher yields were not the most potent against the cancer cell lines.

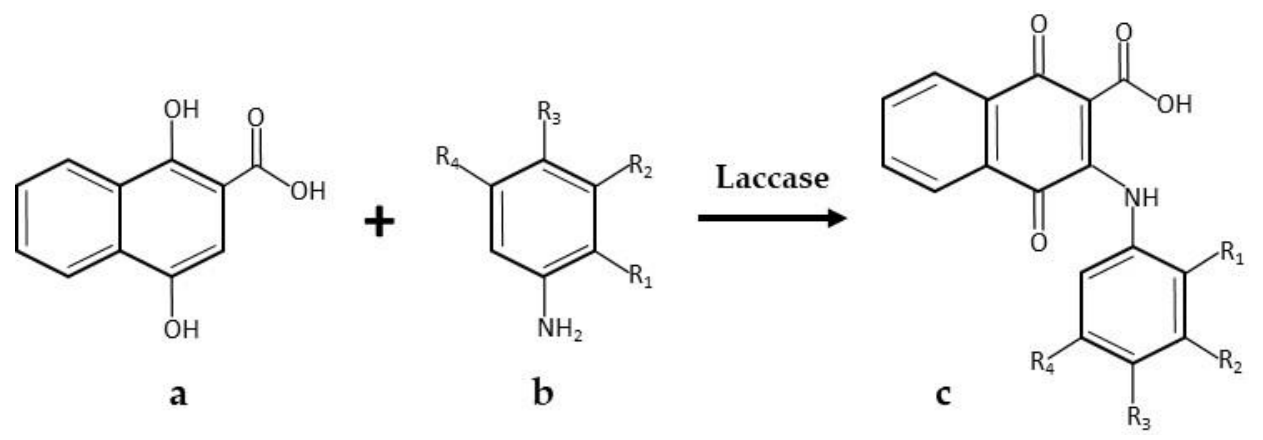

Figure 3. Schematic representation of laccase-catalyzed synthesis of aminonaphthoquinones. (a) 1,4-dihydroxyd-2-naphthoic acid; (b) amine; (c) Aminonaphtoquinone. Adapted from [30]. 
(b) 5,6-dihydroxylated benzo[b]furans and catechol derivatives. For the synthesis of 5,6-dihydroxylated benzo[b]furans, catechols were reacted with 1,3-dicarbonyls, in two different approaches (Figure 4A,B), in a one-pot reaction catalyzed by the commercial laccase Suberase from Myceliophthora thermophila [32]. Synthesis assays were performed varying reaction time and co-solvent dimethylformamide (DMF) concentration, the best yields were obtained for $24 \mathrm{~h}$ (37 to $98 \%$ ) reaction time followed by $44 \mathrm{~h}(49$ to $77 \%$ ) and the lower yields were obtained in the presence of DMF, probably due to a slight deactivation of the laccase Suberase. The authors compared their yields with those previously reported for the same products but applying lipases, chemical or electrochemical synthesis and other laccases different than Suberase. Only one product yield was comparable with that obtained by Pei et al. (2006) in an Oxidation-Michael addition reaction (47\%). The yield of most of the compounds synthesized by laccase Suberase was lower than those previously synthesized by other commercial laccases [Hajdok et al. [49]; Witayakran et al. (2007); Witayakran and Ragauskas (2009)]. Nonetheless, two of the Suberase laccase-synthesized compounds reported by Wellington et al. [32] were obtained in higher yields than those obtained by fungal crude extract, chemical or electrochemical methods [43-47]. The contribution of Wellington et al. [32], with respect to the other authors that synthesized the same 5,6-dihydroxylated benzo[b]furans (Figure $4 \mathrm{Ac}$ ), is the evaluation of cytostatic and cytotoxic effect of the compounds against TK10 (renal), UACC62 (melanoma), MCF7 (breast), HeLA (cervical) cancer cell lines. Several benzo[ $b]$ furans exhibited potent cytostatic effects and weak cytotoxic effects against the cancer cell lines compared to etoposide, being UACC62 cells the most sensible and HeLA cells the most resistant to the majority of the tested benzo[b]furans. Three benzo[b]furans exhibited, in some cases, higher $\mathrm{GI}_{50}$, TGI and $\mathrm{LC}_{50}$ levels against TK10, UACC62 and MCF7 cancer cell lines than etoposide. Comparing the effect of catechols (Figure $5 a$ ), a catechol derivative (Figure $5 b$ ) and benzo[b]furans with etoposide, the authors concluded that the furan rings present in 5,6-dihydroxylated benzo[ $b]$ furans (Figure $5 \mathrm{c}-\mathrm{f}$ ), but not in catechols and the catechol derivative are necessary to enhance anticancer activity. They also highlighted the importance of the methoxy group (Figure $5 \mathrm{~d}$ ) on the benzene ring since the replacement of the methoxy group by a methyl group (Figure $5 e$ ) in two benzo $[b]$ furans diminished their activity against cancer cell lines. The presence of both methoxy and phenyl group, increases the anticancer activity spectrum against the three cancer cell lines TK10, MCF7 and UACC62 since the replacement of the phenyl group by a methyl group (Figure 5f) maintained high activity against MCF7 and UACC62 but decreased the anticancer activity against TK10 cell line.

A<smiles>[R]C1=CC=CC(=O)C1CCCCC(C)(C)C</smiles>

a

B<smiles>[R]c1cccc(O)c1O</smiles>

d

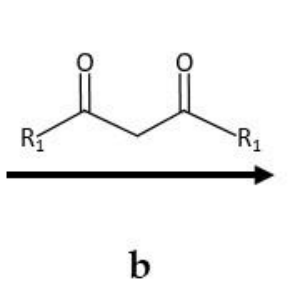

b

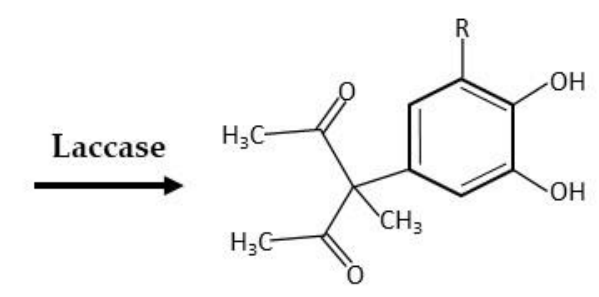

f

Figure 4. Schematic representation of laccase-catalyzed synthesis of 5,6-dihydroxylated benzo[b]furans and catechol derivatives. (a,d) catechol; (b,e) 1,3-dicarbonyl; (c) 5,6-dihydroxylated benzo[b]furan; (f) catechol derivatives. Adapted from [32]. 
<smiles>Oc1cccc(O)c1O</smiles>

a<smiles>COc1c(O)c(O)cc2c3c(oc12)CC(c1ccccc1)CC3=O</smiles>

d<smiles>[R]c1cc(C(C(C)=O)C(C)=O)cc(O)c1O</smiles>

b

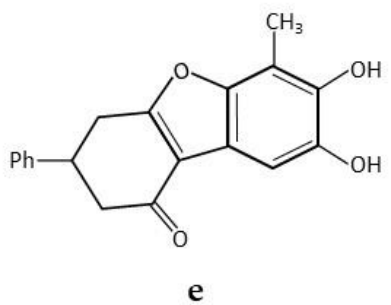<smiles>[R]C(=O)c1c([R])oc2c([R])c(O)c(O)cc12</smiles>

c

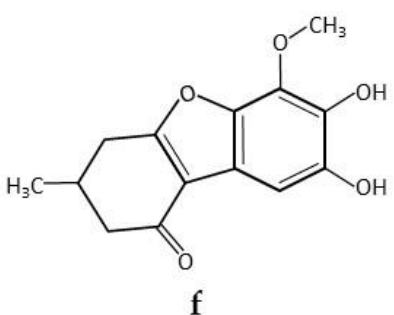

Figure 5. Structures of catechol (a), catechol derivative (b) and 5,6-dihydroxylated benzo[b]furans (c-f). Adapted from [32].

(c) Coumestans derivatives. Previous works have demonstrated the modest anticancer activity of coumestans synthesized by plants. In order to synthesize new coumestans with stronger anticancer activity, Qwebani-Ogunleye et al. (2017) explored the laccase-mediated synthesis of coumestans derivatives [33]. Catechols and coumarins were reacted by laccase Suberase (Figure 6) in a one-pot reaction obtaining fifteen products with yields varying from 70 to $86 \%$. Some of these compounds were previously synthesized in higher yields (94-99\%); but their anticancer activity was never tested before [50-53]. The authors analyzed the $\mathrm{GI}_{50}$, TGI and $\mathrm{LC}_{50}$ levels of the coumestans derivatives against TK10 (renal), UACC62 (melanoma), MCF7 (breast) cancer cell lines and their activity was compared to that of etoposide [33]. The majority of coumestans derivatives exhibited weak and moderate anticancer activity against the three cancer cell lines but all of them in higher $\mathrm{GI}_{50}$ and TGI levels than etoposide. However, one coumestans derivative presented moderate cytostatic activity against melanoma, renal and breast cancer cell lines and another one exhibited potent cytotoxic activity against melanoma and breast cancer cell lines.

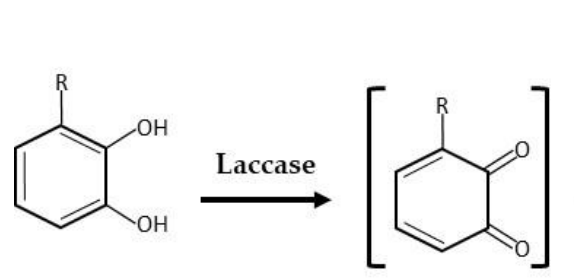

a

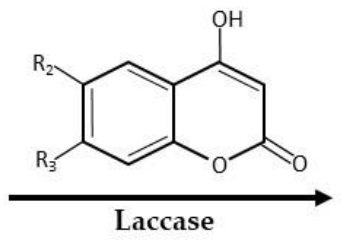

b<smiles>[R9]c1cc2oc(=O)c3c4cc(O)c(O)c(C)c4oc3c2cc1[2H]</smiles>

c

Figure 6. Schematic representation of laccase-catalyzed synthesis of coumestans derivatives.

(a) catechol; (b) coumarin; (c) coumestans. Adapted from [33].

(d) Pyrimidobenzothiazoles and catechol thioethers. With the aim of developing a laccase-catalyzed method to synthesize novel pyrimidobenzothiazoles and catechol thioethers, Abdel-Mohsen et al. (2017) applied a commercial laccase from Agaricus bisporus [34]. Catechol and 2,3-dihydro-2-thioxopyrimidin-4(1H)-ones were used as substrates to synthesize pyrimidobenzothiazoles and catechol thioethers (Figure 7) with yields of up to $97 \%$. To determine the anticancer activity of the synthesized compounds, three pyrimidobenzothiazoles and all of the catechol thioethers were tested by their half minimal inhibitory concentration $\left(\mathrm{IC}_{50}\right)$ against HepG2 (human 
hepatocellular carcinoma) cancer cells and compared with that of doxorubicin, an anticancer agent used as a positive control. Most of the synthesized products exhibited lower antiproliferative activity than doxorubicin although two of them exhibited acceptable $\mathrm{IC}_{50}$ levels. Interestingly, the cytotoxic activity of both pyrimidobenzothiazoles and catechol thioethers seemed to be directly related to their structural composition. In the case of catechol thioethers, substituents present at C-5, C-6 and C-2' determined their $\mathrm{IC}_{50}$ level, the replacement of a methyl group (Figure 8a) at C-6 by $n$-propyl (Figure $8 \mathrm{~b}$ ) increased two-fold the cytotoxic activity, while the presence of an isopropyl group (Figure 8c) at C-6 greatly increased the potency. The activity of a catechol thioether presenting an ethyl group at C-2' (Figure 8d) was ten-fold increased by the addition of an isopropyl group at C-6 increases the activity making this compound the most potent catechol derivative (Figure 8e). On the contrary, the presence of a tert-butyl group at C-6 (Figure 8f), a methyl group at C-5 (Figure 8g) and a bicyclic system (Figure 8h) decreased the activity. In the case of pyrimidobenzothiazoles, the presence of tert-butyl and trifluoromethyl groups (Figure 8i,j, respectively) was favorable since their presence at C-2 in place of the isopropyl group (Figure 8k) increased almost two-fold the antiproliferative activity. An important contribution of the authors was the calculation of factors that support the greenness of the reaction. Authors calculated an E-factor of $4.57 \mathrm{~kg}$ of waste per $\mathrm{kg}$ of product and an atom economy of $94 \%$ for a representative of pyrimidobenzothiazoles, while a representative example of catechol thioethers had an E-factor of $5 \mathrm{~kg} \mathrm{~kg}^{-1}$ and atom economy of $94 \%$. For the synthesis of the representative pyrimidobenzothiazoles, high values were obtained for the turnover number (up to 4656) and the turnover frequency of the laccases (up to $308.57 \mathrm{~h}^{-1}$ ).

A<smiles>Oc1ccccc1O</smiles>

a

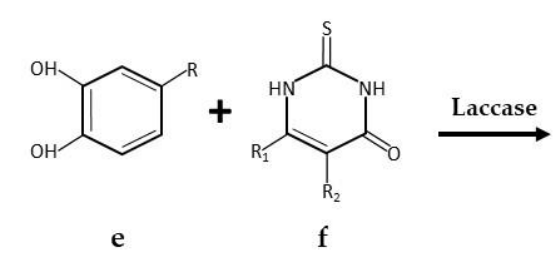<smiles>Cc1nc2sc3cc(O)c(O)cc3n2c(=O)c1C</smiles>

c

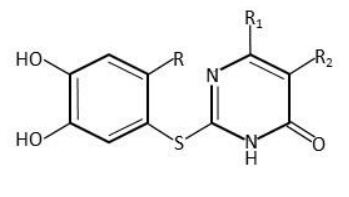

$\mathrm{g}$

Figure 7. Schematic representation of laccase-catalyzed synthesis of pyrimidobenzothiazoles derivatives (A) and catechol thioethers (B). (a,c) catechol; (b,f) 2,3-dihydro-2-thioxopyrimidin-4(1H)-ones; (e,d) pyrimidobenzothiazoles; (g) catechol thioethers. Adapted from [34]. 
<smiles>Cc1cc(=O)[nH]c(Sc2cc(O)c(O)cc2C)n1</smiles>

a<smiles>CCc1cc(O)c(O)cc1Sc1nc(C(F)(F)F)cc(=O)[nH]1</smiles>

d<smiles>CCc1cc(O)c(O)cc1Sc1nc(C)c(C)c(=O)[nH]1</smiles>

g<smiles>O=c1cc(C(F)(F)F)nc2sc3cc(O)c(O)cc3n12</smiles><smiles>Cc1cc(O)c(O)cc1Sc1nc(CCF)cc(=O)[nH]1</smiles>

b<smiles>Cc1cc(O)c(O)cc1Sc1nc(C(F)(F)F)cc(=O)[nH]1</smiles>

e<smiles>Cc1cc(O)c(O)cc1Sc1nc2c(c(=O)[nH]1)CCC2</smiles>

h<smiles>[X]c1cc(=O)n2c(n1)sc1cc(O)c(O)cc12</smiles><smiles>Cc1cc(O)c(O)cc1Sc1nc(C(F)(F)F)cc(=O)[nH]1</smiles>

c<smiles>CCc1cc(O)c(O)cc1Sc1nc(C)cc(=O)[nH]1</smiles>

f<smiles>O=c1cc(C(F)(F)F)nc2sc3cc(O)c(O)cc3n12</smiles>

Figure 8. Structures of the catechol thioethers $(\mathbf{a}-\mathbf{h})$ and pyrimidobenzothiazoles $(\mathbf{i}-\mathbf{k})$. Adapted from [34].

\subsubsection{Laccase-Synthesized Molecules with Antioxidant Activity}

Polyphenols are secondary metabolites present in most plants, these compounds have free radical scavenging and metal chelating activities that make them attractive compounds to treat and prevent cancer, diabetes, atherosclerosis, rheumatoid arthritis, asthma, cardiovascular diseases, Alzheimer's and Parkinson's disease, etc., which are mediated by excessive cellular accumulation of free radicals [54]. In contrast to monomeric polyphenols, polymeric forms can overcome short antioxidant action time, toxic effects due to excessive absorption, low water solubility and pro-oxidant effect of monomer polyphenols. Previous works have demonstrated the efficient enzymatic polymerization of polyphenols, which in turn increases the antioxidant activity and water solubility of polymer polyphenols [55]. Kurisawa et al. (2003) reported the polymerization of rutin by laccase from Myceliophthora. Rutin polymer was readily soluble in water, contrary to the monomer, and exhibited an increased superoxide scavenging activity [56]. Desentis-Mendoza et al. (2006) reported the polymerization of quercetin and kaempferol by laccase and tyrosinase from Ustilago maydis resulting in higher antioxidant activity than that of monomer forms [57]. A limiting factor of using laccases to synthesize polyphenols polymers is the poor solubility of substrates, although it could be circumvented by the use of environmentally friendly co-solvents. Recent works that have improved laccase polymerization of polyphenols in accordance with green chemistry principles are addressed below.

(a) Polyrutin and polyesculin. Rutin $(611.21 \mathrm{~g} / \mathrm{mol})$ and esculin $(339.36 \mathrm{~g} / \mathrm{mol})$ were polymerized by a Trametes versicolor laccase catalyzed reaction in the presence of $30 \%$ of methanol to allow the solubility of polyphenols [36]. Five fractions of polyrutin were obtained in a molecular weight 
range from 2127.42 to $8331.85 \mathrm{~g} / \mathrm{mol}$ and five polyesculin fractions from 688.12 to $6973 \mathrm{~g} / \mathrm{mol}$. The FTIR spectra of rutin and esculin and their respective polymerized fractions showed that the polymerization of polyrutin fractions was due to $\mathrm{C}-\mathrm{O}$ and $\mathrm{C}-\mathrm{C}$ bonds while the polymerization of polyesculin fractions was due to $\mathrm{C}-\mathrm{C}$ bonds. The antioxidant activity of rutin, esculin and their polymer derivatives was demonstrated by radical scavenging on ABTS and DPPH, iron chelating capacity, xanthine oxidase (XO) inhibition assay, and cupric reducing antioxidant capacity (CUPRAC). Results showed that the antioxidant activity of polyrutin fractions expressed as $\mathrm{IC}_{50}$ values for ABTS, DPPH and hydroxyl radical decreased as weight-average molecular mass increased. This reduction of antioxidant-activity could be probably due to a loss of free hydroxyl groups on $C 4^{\prime}, C 3^{\prime}$ and $C 7^{\prime}$ during rutin polymerization. In contrast, the $\mathrm{XO}$ inhibition activity, the iron chelating capacity and CUPRAC assays showed the opposite, polyrutin showed higher antioxidant activity than rutin. In the case of polyesculin, antioxidant-activity $\left(\mathrm{IC}_{50}\right.$ values for $\mathrm{ABTS}$, and hydroxyl radical) increased as weight-average molecular mass increased, indicating a stronger antiradical activity than esculin monomer. This can be explained because of the groups implicated in the antioxidant activity were not affected during polymerization. While the $\mathrm{IC}_{50}$ for DPPH remained constant suggesting that DPPH scavenging activity is independent of polymerization degree. Polyesculin fractions also exhibited higher $\mathrm{XO}$ inhibition activity, iron chelating properties, and CUPRAC capacities than esculin [36]. The strong xanthine oxidase inhibition showed by polyrutin and polyesculin make them good candidates to attack gout disease, and probably another of the above-mentioned diseases.

(b) Catechin polymers. With the aim of improving laccase stability and catechin polymerization, Jadhav and Singhal (2013) conjugated laccase from Trametes versicolor with gum Arabic [35]. The ability of conjugated laccase to polymerize catechin was compared with free laccase under optimized reaction conditions (Table 1). Different aqueous mixtures of organic co-solvents (acetonitrile, methanol, ethylene glycol and dimethyl sulphoxide) were used to solubilize catechin. Different parameters such as enzyme and substrate concentration and $\mathrm{pH}$ were optimized. Results showed a high production of catechin polymer when methanol was used as co-solvent. In methanol, the conjugated laccase presented lower activity than free laccase but higher stability. Also, the conjugated laccase produced water-soluble and fusible linear catechin polymer, in contrast to water-insoluble and infusible cross-linked catechin polymer synthesized by the free laccase. Antioxidant activity (determined by DPPH assay) and reducing power of the linear catechin polymer were higher than catechin monomer. This work demonstrated that laccase conjugation is an interesting approach to improve product yield and antioxidant activity of polyphenol polymers [35].

As already mentioned, catechin polymerization reaction requires the addition of an organic solvent to solubilize catechin in water. In order to replace toxic solvents with environmentally friendly solvents, deep eutectic solvents (DES) can be an alternative, due to low toxicity and high biodegradability. For catechin polymerization, Ünlü et al. (2017) tested different DES types as choline chloride with glycerol (ChCl-G) or with ethylene glycerol (ChCl-EG), and betaine:mannose (B-M), a natural deep eutectic solvent (NADES), and compared their effect on catechin polymerization with acetone as a reference co-solvent [37]. Different laccase amount, DES and NADES content, and reaction time were tested. Results demonstrated that laccase from Trametes versicolor is active in the presence of DES and NADES but the higher molecular weight catechin polymer $\left(4354 \pm 678 \mathrm{~g} \mathrm{~mol}^{-1}\right)$ at the highest yield $(83 \pm 6 \%$ ) was obtained in $5 \%(v / v)$ B-M with $125 \mathrm{U}$ of laccase (Table 1$)$. All synthesized catechin polymers exhibited higher antioxidant activities than catechin monomer. Although, the catechin polymer that exhibited the highest values of both XO inhibitory activity and superoxide radical scavenging was synthesized with $62.5 \mathrm{U}$ of laccase in $5 \%(v / v) \mathrm{B}-\mathrm{M}$ and had a molecular weight of $4177 \pm 405 \mathrm{~g} \mathrm{~mol}^{-1}$.

\subsubsection{Laccase-Synthesized Molecules with Antibiotic Activity}

The accelerated development of resistance to antibiotics is putting human and animal health at risk in all parts of the world. The treatment of hard infections such as pneumonia, tuberculosis, gonorrhea, 
etc. is becoming harder even impossible with the present arsenal of antibiotics [48]. Therefore, the urgent need for novel antibiotics has pushed the development of drugs against multidrug-resistant bacteria [58]. An interesting approach that could be immediate and less time-consuming than exploring new antibiotic niches or biological sources is the modification of existing antibiotics to their bioactive derivatives $[19,59]$. The use of laccases for the enzymatic transformation of antibiotics was initially proposed by Agematu et al. [60] and has been extensively explored by Mikolasch's team [19].

$\beta$-lactam antibiotics. In their most recent work, Mikolasch et al. (2012) synthesized seven novel $\beta$-lactam antibiotics by laccase-catalyzed amination of 2,5-dihydrophenylacetic acid (see reaction conditions in Table 1) [39]. The growth inhibitory activity of the new $\beta$-lactam antibiotics was tested against Gram-positive strains including the multidrug-resistant strains Staphylococcus and Enterococcus. Two of the products showed antibacterial activity against the majority of the strains. Furthermore, none of the new $\beta$-lactam antibiotics was cytotoxic against a human amniotic epithelial cell line. In vivo assays demonstrated the effectiveness of the majority of the $\beta$-lactam antibiotics in immune-suppressed mice infected with S. aureus ATCC 6538. In contrast, untreated mice died.

\subsubsection{Laccase-Synthesized Molecules with Antidiabetic Activity}

Diabetes is one of the chronic diseases with higher prevalence all around the world. The prevalence of diabetes worldwide in 2000 was estimated to be 171 million and projections for 2030 are 366 million [61]. Recently Jeon (2013) demonstrated the in vivo application of laccase polymerized catechin as an alternative pharmaceutical to control glucose absorption by inhibiting $\alpha$-glucosidase, the enzyme that releases absorbable $\alpha$-glucose [41]. It should be interesting to determine if laccase biosynthesis of catechin polymers is less expensive than insulin production or other antidiabetic drugs.

Catechin polymers. Catechin was polymerized by laccase from Aspergillus oryzae (Denilte IIS) at room temperature (Table 1). After laccase polymerization, various catechin polymer fractions were extracted with increasing ethanol (10-100\%) and acetone (80-100\%) concentrations. The $\alpha$-glucosidase inhibitory activity (expressed as the concentration requires for $50 \%$ inhibition of the enzyme activity, $\mathrm{IC}_{50}$ ) of catechin polymer fractions, was assayed in vitro and compared with that of catechin monomer and theaflavins (prepared from black tea). The highest antiglycation activity ( $\mathrm{IC}_{50} 4 \mu \mathrm{g} / \mathrm{mL}$ ) was exhibited by the catechin polymer fraction extracted with $20 \%$ ethanol, which was 70 -fold higher than catechin monomer. LC-MS analysis of the $20 \%$ ethanol fraction showed a composition of dimers, trimers and tetramers with molecular weights of 575,863 and $1151 \mathrm{Da}$, respectively. In order to validate the antidiabetic effect of total catechin polymers, mice were supplied with $200 \mathrm{mg} / \mathrm{kg}$ of catechin monomer or catechin polymers and $5 \mathrm{~min}$ later were fed with $1 \mathrm{~g} / \mathrm{kg}$ of maltose solution. Blood glucose $(\mathrm{mg} / \mathrm{mL})$ was monitored over the time showing a significant decrease of glucose in mice supplied with catechin polymers compared to mice supplied with catechin monomer or control mice. Because of a hyperglycemic condition, the formation of advanced glycation products (AGEs) and oxidative stress are accelerated, antiglycation effect and superoxide-dismutase like (SOD-like) activity of catechin, catechin polymers and $20 \%$ ethanol-extract catechin polymers were examined. Catechin polymers showed higher antiglycation activity than monomers. Therefore, catechin polymers can be applied for the treatment of type 2 diabetes and other diabetic complications [61].

\section{Limitations for Laccase-Mediated Synthesis of Fine Chemicals at Large-Scale}

Although results described above are promising for the laccase-mediated synthesis of fine chemicals and methods are potentially transferable to the commercial scale, most of the current literature underline that more work has to be done in order to improve laccase yields and properties [62]. There is a tendency to assume that laccase price limited their application at commercial scale. Although it could be true for industrial effluent treatment, there is a vast range of possibilities for fine chemical synthesis. The enzyme stability and availability are to two main factors that limit laccase industrial application. Improving both factors would help to increase the prospects for laccase application at large scales. Regarding the first aspect, stability improvement must be reflected in the increase of the 
total turnover (TTN) number or the space-time yield (STY). In a general way, it has been reported that a TTN value equal or higher than 10,000 (or 1000 for STY) represents a critical value to justify the technical feasibility in the synthesis process of high-quality chemicals such as pharmaceuticals. As mentioned in a previous section, laccases have been reported as efficient biocatalysts in the synthesis of several pharmaceuticals in terms of conversion, selectivity, rapidity, and mild reaction conditions. However, to the best of our knowledge, no reports have been found concerning the quantification of TTN or STY that contribute to determining the technical feasibility of their application. The second factor, enzyme availability, depends on the quantity and cost of the enzyme. Although many enzymes are overproduced by recombinant organisms with high yields and their production processes are economically attractive, laccase overproduction is still under study. In the next sections, the review of the studies about improvements of these two factors is described.

\subsection{Fermentation Yields of Native and Recombinant Laccase-Producers}

Laccases are versatile oxidoreductase enzymes ubiquitously found in plants, fungi, and bacteria. Laccases from white-rot fungi have been extensively studied for several biotechnological purposes [63-66]. In spite of the laccase potential for industrial applications, their use for large-scale processes has been restricted to pulp and paper industries. The successful application of laccases for biotechnological processes requires the production of high amounts of the enzyme at low cost. In order to reduce the costs of laccase production, several aspects have been studied: highly producing strains, fermentation media optimization, proper inducer and bioreactor design [67]. Thus, fungi from genera Cerrena, Coriolopsis and Trametes have produced the highest titer reported (Table 2). Laccase productivities of 350 and $115 \mathrm{U} / \mathrm{mL} / \mathrm{d}$ have been achieved with Cerrena unicolor and a white rot fungus WR-1 $[68,69]$. Other native fungal strains include the bacterium Bacillus subtilis, which can produce up to $275 \mathrm{U} / \mathrm{mL} / \mathrm{d}$ [70]. Compare with fungal laccases, bacterial laccases are barely affected by sodium chloride or Tween- 80 and have proved to be more robust at high $\mathrm{pH}$ and temperature. Bacterial laccases show high activity in the presence of up to 50\% DMSO [70-74], presenting attractive industrial features required under extreme process conditions.

Several reports claim that laccase yields of native producers are too low to be considered for commercial applications and suggest that recombinant laccase production in popular hosts may be a feasible strategy to increase enzyme yields $[73,75,76]$. However, results shown in Table 2 do not support such idea; on contrary, yields and productivities obtained by the expression in homologous microorganisms are higher than those of heterologous expression (Table 2). Several challenges are faced when cloning and expressing recombinant laccases: incompatible codon usage of hosts, post-translational modifications, lacking chaperones, disulfide bridges [64]. Heterologous expression of functional fungal laccases in Escherichia coli (most popular host) is difficult, resulting in the formation of inclusion bodies in most cases [77]. Conversely, recombinant laccase production in yeast and filamentous fungi have been more successful; but still lower than yields attained by native producers (Table 2). In order to meet laccase production levels for industrial applications, laccase overexpression into native hyper-producer strains should be more extensively studied as an alternative to decrease laccase cost production. Pleurotus ostreatus, Polyporus brumalis and Gloeophyllum trabeum fungal strains have been transformed for laccase homologous overexpression by different methods [78-80]. The constitutive overexpression of laccase in P. brumalis under the control of the glyceraldehyde- 3-phosphate dehydrogenase promoter increased laccase activity 4 times higher than that of the wild-type strain [79]. There is no doubt that heterologous expression can circumvent the use of poisonous elicitors required in traditional fungal-laccase production beside to allowing directed evolution experiments to produce upgraded laccases with novel biochemistry properties and desirable stability [18]. Therefore, the recombinant approach of laccase production should be still investigated. 
Table 2. Maximum laccase activities obtained by native and recombinant producers.

\begin{tabular}{|c|c|c|c|c|c|}
\hline Microorganism & $\begin{array}{l}\text { Activity Yield } \\
\text { (U/mL) }\end{array}$ & $\begin{array}{c}\text { Laccase } \\
\text { Productivity } \\
\text { (U/mL/d) }\end{array}$ & Fermentation Type & Inducer & Reference \\
\hline \multicolumn{6}{|l|}{ Native fungal strains } \\
\hline Cerrena unicolor strain C-139 & 250 and 450 & 35.7 and 32.1 & SmF, shake flask, $150 \mathrm{rpm}, 30^{\circ} \mathrm{C}$ & $\begin{array}{l}1 \mathrm{mMCu}^{2+} \text {, } \\
\text { wheat bran }\end{array}$ & [81] \\
\hline Cerrena unicolor strain C-139 & 416.4 & 34.7 & SmF, $120-\mathrm{L}$ STR $(130-420 \mathrm{rpm}), 30^{\circ} \mathrm{C}$ & $\begin{array}{l}1 \mathrm{mMCu}^{2+}, \\
\text { wheat bran }\end{array}$ & [82] \\
\hline Cerrena sp. strain HYB07 & 280 & 56 & SmF, shake flask, $200 \mathrm{rpm}, 30^{\circ} \mathrm{C}$ & $0.25 \mathrm{mM} \mathrm{Cu}^{2+}$ & [83] \\
\hline Cerrena unicolor strain GSM- 01 & $2800 *$ & 350 & SmF, shake flask, $170 \mathrm{rpm}, 28^{\circ} \mathrm{C}$ & $1.0 \mathrm{mM} \mathrm{Cu}^{2+}$ & [69] \\
\hline Cerrena sp. WR1 & 202 & 15.5 & SmF, 5-L STR (200 rpm), $25^{\circ} \mathrm{C}$ & $2 \mathrm{mM} 2,5$-xylidine & [84] \\
\hline Coriolopsis gallica 1184 & 200.9 & 28.7 & SmF, 50-L STR, (200-300 rpm), $30^{\circ} \mathrm{C}$ & $0.2 \mathrm{mM}$ Vanillin & [85] \\
\hline Trametes pubescens & 333 and 743 & 19.7 and 25.7 & SmF, 20-L STR (100 rpm), $25^{\circ} \mathrm{C}$ & $2 \mathrm{mMCu}^{2+}$ & [86] \\
\hline white rot fungus WR-1 & 692 & 115 & SmF, shake flask, $150 \mathrm{rpm}, 28^{\circ} \mathrm{C}$ & $\begin{array}{l}0.8 \mathrm{mM} 2,5 \text {-xylidine, } \\
1 \mathrm{mM} \mathrm{Cu}^{2+}\end{array}$ & [68] \\
\hline \multicolumn{6}{|l|}{ Native bacterial strains } \\
\hline Arthrospira maxima & 56.9 & 14.2 & $\begin{array}{l}\text { SmF, shake flask, swirled twice a day } \\
\text { for mixing, } 30^{\circ} \mathrm{C}\end{array}$ & $\begin{array}{l}0.1 \mathrm{mM}_{\text {guaiacol}}, \\
2 \mathrm{mM} \mathrm{Cu}^{2+}\end{array}$ & [87] \\
\hline Bacillus subtilis DS & $820^{\mathrm{a}}$ & 205 & SmF, shake flask, NA rpm, $37^{\circ} \mathrm{C}$ & $\begin{array}{c}0.15 \mathrm{mM} \text { vanillic } \\
\text { acid, } 0.15 \mathrm{mM} \\
\mathrm{MgSO}_{4} \\
5 \times 10^{-5} \mathrm{mM} \mathrm{Cu}^{2+}\end{array}$ & [88] \\
\hline Bacillus tequilensis SN4 & $1101^{\mathrm{b}}$ & 275 & SmF, shake flask, $150 \mathrm{rpm}, 30^{\circ} \mathrm{C}$ & $\begin{array}{c}0.65 \mathrm{mM} \mathrm{MnSO}_{4} \\
0.35 \mathrm{mM} \mathrm{FeSO}_{4}, 3.5 \% \\
\text { Ethanol }\end{array}$ & [70] \\
\hline \multicolumn{6}{|l|}{ Recombinant laccase source (Host) } \\
\hline Trametes sp. C30 (Aspergillus niger) & $42^{\mathrm{a}}$ & 6 & SmF, 0.5-L STR, (NA rpm), $28^{\circ} \mathrm{C}$ & NA & [89] \\
\hline $\begin{array}{l}\text { Gaeumannomyces graminis } \\
\text { (Cryptococcus sp. S-2) }\end{array}$ & 380 & 47.5 & SmF, 2-L STR, (NA rpm), $25^{\circ} \mathrm{C}$ & $1.2 \mathrm{mMCu}^{2+}$ & [90] \\
\hline Cerrena sp. HYB07 (Pichia pastoris) & 6.3 & 0.7 & SmF, shake flask, $200 \mathrm{rpm}, 30^{\circ} \mathrm{C}$ & $1 \mathrm{mMCu} 2+$ & [91] \\
\hline Pleurotus ostreatus (Aspergillus niger) & 60 & 12 & SmF, shake flask, $150 \mathrm{rpm}, 28^{\circ} \mathrm{C}$ & $\begin{array}{l}0.1 \mathrm{mM} \mathrm{Cu}^{2+}, \\
0.2 \mathrm{mM} \mathrm{ABTS}\end{array}$ & [92] \\
\hline Pleurotus ostreatus (Pichia pastoris) & 60 & 15 & $\begin{array}{l}\text { SmF, Fed-batch fermentation, NA rpm, } \\
\qquad 28^{\circ} \mathrm{C}\end{array}$ & glycerol & [75] \\
\hline Trametes sp. 420 (Pichia pastoris) & 239 & 31.8 & $\begin{array}{l}\text { SmF, Fed-batch fermentation, NA rpm, } \\
\qquad 28^{\circ} \mathrm{C}\end{array}$ & NA & [93] \\
\hline $\begin{array}{l}\text { Trametes versicolor } \\
\text { (Pichia pastoris GS115) }\end{array}$ & 34.2 & 2.3 & SmF, shake flask, $180 \mathrm{rpm}, 28^{\circ} \mathrm{C}$ & $\begin{array}{l}0.5 \mathrm{mM} \mathrm{Cu}^{2+} 0.6 \% \\
(v / v) \text { methanol }\end{array}$ & [94] \\
\hline $\begin{array}{l}\text { Escherichia coli K12 } \\
\text { (Pichia pastoris GS115) }\end{array}$ & 41 & 8 & SmF, 5-L STR, NA rpm, $28^{\circ} \mathrm{C}$ & $\begin{array}{l}0.5 \mathrm{mM} \mathrm{Cu}^{2+} 0.6 \% \\
(v / v) \text { methanol }\end{array}$ & [73] \\
\hline $\begin{array}{l}\text { Bacillus subtilis } 168 \\
\text { (Escherichia coli BL21) }\end{array}$ & 13.8 & 9.7 & SmF, shake flask, $200 \mathrm{rpm}, 37^{\circ} \mathrm{C}$ & $\begin{array}{c}1 \text { mM IPTG, } \\
\text { micro-aerobic } \\
\text { cultivation }\end{array}$ & [95] \\
\hline Bacillus pumilus CotA (Escherichia coli) & 4.2 & 4.5 & SmF, shake flask, $160 \mathrm{rpm}, 30^{\circ} \mathrm{C}$ & $\begin{array}{c}1 \mathrm{mM} \mathrm{IPTG} 0.25 \mathrm{mM} \\
\mathrm{CuCl}_{2} \text {, oxygen } \\
\text { limitation }\end{array}$ & [96] \\
\hline
\end{tabular}

* Unless otherwise mentioned, enzyme activity was assayed with ABTS ([2,2'-azinobis(3-ethylenthiazoline6-sulphonate) as the substrate at $420 \mathrm{~nm}$. NA, not available. a syringaldazine as the substrate at $525 \mathrm{~nm}$.

b 2,6-dimethoxy-phenol (2 mM) (DMP) was used as substrate. SmF: submerged fermentation, STR: stirred tank reactor.

\subsection{Laccase Immobilization}

As mentioned earlier, the operation stability of laccase enzymes still must be strengthened in order to be applied at large scales. One of the strategies to improve this parameter is to immobilize the enzyme over organic, inorganic or hybrid materials [97]. Enzyme immobilization is a mature technology. However, it is still prevailing because of the fabrication of materials with novel physicochemical properties that would potentially allow the stabilization of the biological molecule for sufficiently long periods of time. This would, in turn, make economically feasible the application of the enzymes in industrial processes. The advantages of enzyme immobilization can be summed up as follows: it improves stability (thermostability, structural stability, $\mathrm{pH}$ stability, and changes in environmental conditions stability); recovery and reuse of the enzyme are easier; and product purification is relatively easy [98]. On the other hand, immobilization generally decreases enzymatic activity sharply due to stiffening or partial denaturing of its structure when it is bonded to a solid surface. The extent of 
improvement or decrease in biocatalytic functions depends whether on the immobilization technique, on the nature of the material or on the enzyme. Another disadvantage is that the volume of the catalyzer is highly increased, which implies a larger reactor size compared to that calculated for the free enzyme. Nonetheless, the immobilizing support plays a key role in some physicochemical properties that may benefit (or sometimes may be detrimental to) the biocatalytic functions to the extent where it can become the determining factor of the improvement of enzyme performance. For instance, it can improve the partition or selectivity of the substrate towards the enzyme active site, it can favor the repulsion or adsorption of inhibitory products, it can provide a buffered microenvironment to the reaction conditions, etc. The objective of enzyme immobilization is to improve the biocatalytic performance regardless of the responsible molecular or physicochemical events. Most studies about laccase application and immobilization deal with the transformation of environmental contaminants. This section will summarize the results about the improvement of the laccase biocatalytic behavior applied on the transformation of pharmaceutical compounds, although the main objective was their degradation as micropollutants (Table 3). Current research investigations focused on enzyme immobilization using nanomaterials have shown advantages in terms of the quantity of the immobilized enzyme and the kinetics $[99,100]$. One remarkable outcome of using nanomaterials is the improvement of the enzyme stability measured as the residual catalytic activity after a given number of reaction cycles. The stabilization of laccase in an unprecedented number of cycles was recently reported. Kumar and Cabana (2018) attained to keep the enzyme's catalytic activity after hundred and fifty batch reactions. To do it, the enzyme was immobilized as cross-linked enzyme aggregates (MAC-CLEAs) on amine-functionalized magnetic nanoparticles using chitosan [101]. Rouhani et al. (2018) achieved laccase stabilization for up to 10 reaction cycles with only a $10 \%$ loss of initial activity when it was immobilized in a Graphene oxide/ $\mathrm{CuFe}_{2} \mathrm{O}_{4}$ nanocomposite for the synthesis of arylsulfonyl benzenediols [102]. Other reports show that immobilized laccase in $\mathrm{Cu}$ (II)-chelated chitosan-graft-poly (glycidyl methacrylate) nanoparticles and Polyacrylonitrile-biochar composite nanofibrous membrane was stable, with a loss of about $50 \%$ after 7 reaction cycles $[103,104]$. Good results in terms of stability and activity have also been reported after immobilizing laccase in other kinds of more conventional materials. Hommes et al. (2012) reported an increase in laccase catalytic behavior (around 164\%) when immobilized in fumed silica. Furthermore, the immobilized enzyme showed a high stability when kept active for 7 days [105]. In another study, Nguyen et al. (2016) immobilized laccase in granulated activated carbon and reported that the whole system (activated carbon and laccase) showed a high performance maintaining its capability to oxidize sulfamethoxazole, carbamazepine, diclofenac and bisphenol A for two months [106]. In a strategy of synthetic biology, a fungal laccase was immobilized on the surface of yeast cells and was used as a biocatalyzer to oxidize bisphenol A and sulfamethoxazole. The immobilized laccase retained over $90 \%$ of the initial enzyme activity after 25 days storage at room temperature, while, the activity of free laccase declined up to $60 \%$ of its initial activity. The immobilized laccase could be reused while retaining $74 \%$ of initial activity after eight repeated batch reactions [107].

Table 3. Recent examples of laccase immobilization.

\begin{tabular}{|c|c|c|}
\hline Immobilization System & Result & Reference \\
\hline Chitosan crosslinked with genipin & $\begin{array}{l}\text { Improved } \mathrm{pH} \text {, thermal, and storage stabilities of when compared with the } \\
\text { free counterpart. The chitosan laccase system exhibited a residual activity } \\
\qquad \text { of }>55 \% \text { after } 11 \text { cycles }\end{array}$ & [109] \\
\hline $\begin{array}{l}\text { polyacrylonitrile-biochar composite } \\
\text { nanofibrous membrane }\end{array}$ & High conversion for after $8 \mathrm{~h}$ of reaction & [110] \\
\hline
\end{tabular}


Table 3. Cont.

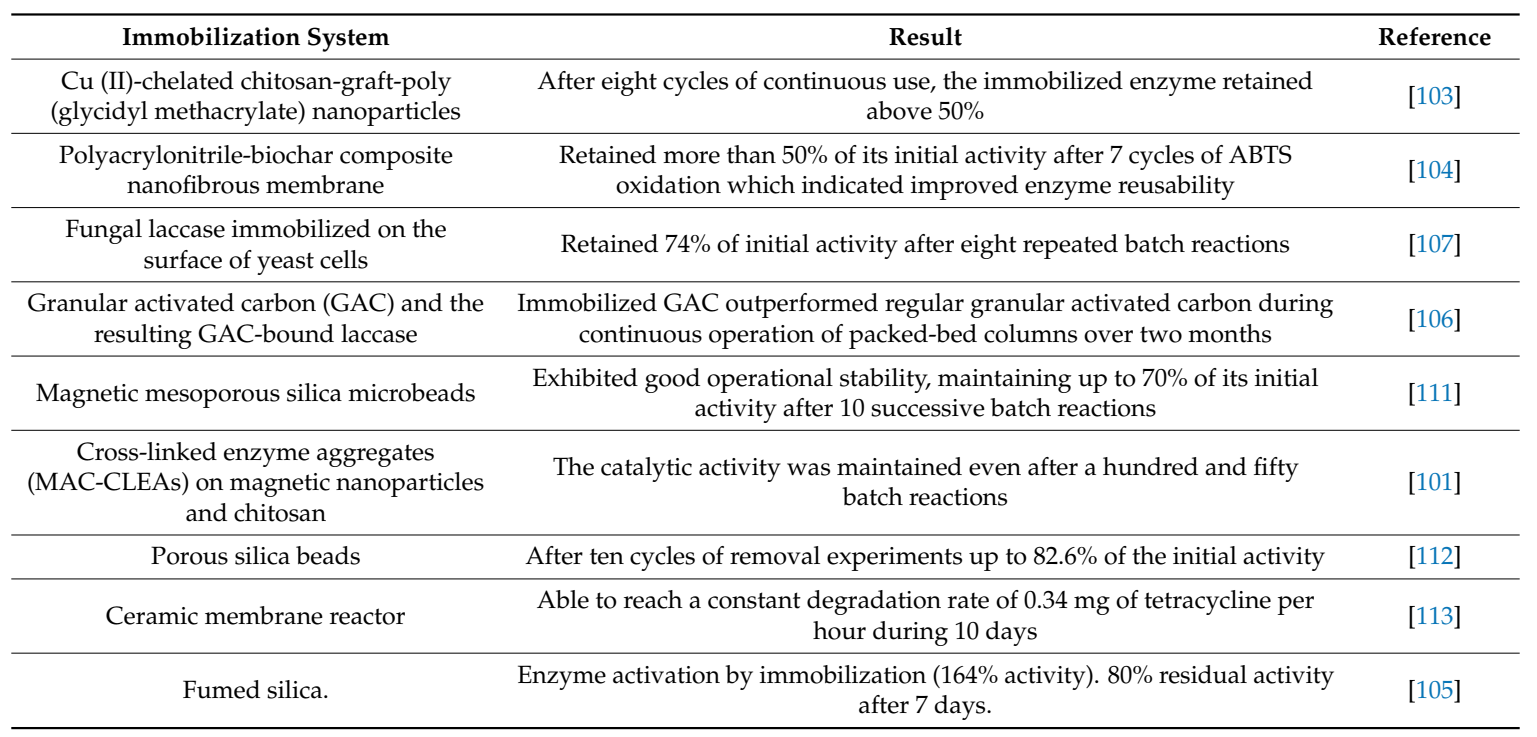

\section{Conclusions and Perspectives}

The application of laccases as catalysts in the synthesis of fine chemicals presents an interesting alternative to conventional chemical processes given the demonstrated sustainability of biotechnological processes. However, there are no commercial applications of laccases for synthesis purposes, even though the feasibility of using laccases has been demonstrated in some large-scale processes [22]. In addition, immobilization techniques would help to improve laccase performance for the oxidation of pharmaceutical compounds. Although laccase production costs seem to be high for the commercial enzyme-based process, it is probable that development of better enzyme production procedures and the use of molecular biology tools could reduce the enzyme production expenses. In this regard, a low selling price of $\$ 0.42 \mathrm{USD} / \mathrm{kU}$ was estimated through a techno-economic analysis for recombinant laccase production in Pichia pastoris, when culture reached just $15 \mathrm{U} / \mathrm{mL} / \mathrm{d}$ [75]. Higher laccase productivities have been already achieved (Table 1), suggesting that laccase-selling price could be lower than $\$ 0.42 \mathrm{USD} / \mathrm{kUs}$.

Considering the cost of the catalyst itself is not the best way to compare its feasibility, the cost contribution of catalyst to the final product should be more appropriate. There are still further approaches to make laccase-mediated synthesis affordable. For example, coupling laccase synthesis with different deep and natural eutectic solvents to replace organic solvents, modifying the redox potential and the $\mathrm{pH}$ range of laccases by molecular evolution to improve reaction yields, and increasing laccase stability. Since laccases have shown encouraging potential as biocatalysts in the synthesis of drugs with high chemo-, regio- and enantioselectivities, their prices can be reasonable or even low for production of expensive active pharmaceutical ingredients on a commercial scale.

Author Contributions: C.R.-G., A.B. and E.T. decided the structure and content of the manuscript; C.R.-G., A.B. and E.T. performed the bibliographical research, analyzed the information, generated all figures and tables and wrote the manuscript.

Acknowledgments: This research was partially supported by PRODEP/511-6/17-8017.

Conflicts of Interest: The authors declare no conflict of interest.

\section{References}

1. Clarke, C.J.; Tu, W.C.; Levers, O.; Bröhl, A.; Hallett, J.P. Green and Sustainable Solvents in Chemical Processes. Chem. Rev. 2018, 118, 747-800. [CrossRef] [PubMed] 
2. Constable, D.J.C.; Jimenez-Gonzalez, C.; Henderson, R.K. Perspective on solvent use in the pharmaceutical industry. Org. Process. Res. Dev. 2007, 11, 133-137. [CrossRef]

3. Sheldon, R.A. The E Factor: Fifteen years on. Green Chem. 2007, 9, 1273-1283. [CrossRef]

4. Sheldon, R.A. The E factor 25 years on: The rise of green chemistry and sustainability. Green Chem. 2017, 19, 18-43. [CrossRef]

5. Bornscheuer, U.T.; Huisman, G.W.; Kazlauskas, R.J.; Lutz, S.; Moore, J.C.; Robins, K. Engineering the third wave of biocatalysis. Nature 2012, 485, 185-194. [CrossRef] [PubMed]

6. Sun, H.; Zhang, H.; Ang, E.L.; Zhao, H. Biocatalysis for the synthesis of pharmaceuticals and pharmaceutical intermediates. Bioorg. Med. Chem. 2018, 26, 1275-1284. [CrossRef] [PubMed]

7. Wells, A.; Meyer, H.P. Biocatalysis as a Strategic Green Technology for the Chemical Industry. ChemCatChem 2014, 6, 918-920. [CrossRef]

8. Sheldon, R.A. Engineering a more sustainable world through catalysis and green chemistry. J. R. Soc. Interface 2016, 13, 20160087. [CrossRef] [PubMed]

9. Sheldon, R.A. Green solvents for sustainable organic synthesis: State of the art. Green Chem. 2005, 7, $267-278$. [CrossRef]

10. Wohlgemuth, R. Green Production of Fine Chemicals by Isolated Enzymes. In Biocatalysis for Green Chemistry and Chemical Process Development; Kazlauskas, R., Tao, J., Eds.; John Wiley \& Sons: Hoboken, NJ, USA, 2011; Volume 1, pp. 277-298. ISBN 9780470437780.

11. Choi, J.M.; Han, S.S.; Kim, H.S. Industrial applications of enzyme biocatalysis: Current status and future aspects. Biotechnol. Adv. 2015, 33, 1443-1454. [CrossRef] [PubMed]

12. Schulze, B.; Wubbolts, M.G. Biocatalysis for industrial production of fine chemicals. Curr. Opin. Biotechnol. 1999, 10, 609-615. [CrossRef]

13. Rose, A.S.; Bradley, A.R.; Valasatava, Y.; Duarte, J.M.; Prlić, A.; Rose, P.W. Web-based molecular graphics for large complexes. In Proceedings of the 21st International Conference on Web3D Technology, Anaheim, CA, USA, 22-24 July 2016; pp. 185-186.

14. Rose, A.S.; Hildebrand, P.W. NGL Viewer: A web application for molecular visualization. Nucleic Acids Res. 2015, 43, W576-W579. [CrossRef] [PubMed]

15. Matera, I.; Gullotto, A.; Tilli, S.; Ferraroni, M.; Scozzafava, A.; Briganti, F. Crystal structure of the blue multicopper oxidase from the white-rot fungus Trametes trogii complexed with $p$-toluate. Inorg. Chim. Acta 2008, 361, 4129-4137. [CrossRef]

16. Solomon, E.I.; Baldwin, M.J.; Lowery, M.D. Electronic structures of active sites in copper proteins: Contributions to reactivity. Chem. Rev. 1992, 92, 521-542. [CrossRef]

17. Augustine, A.J.; Kjaergaard, C.; Qayyum, M.; Ziegler, L.; Kosman, D.J.; Hodgson, K.O.; Hedman, B.; Solomon, E.I. Systematic Perturbation of the Trinuclear Copper Cluster in the Multicopper Oxidases: The Role of Active Site Asymmetry in Its Reduction of $\mathrm{O}_{2}$ to $\mathrm{H}_{2}$ O. J. Am. Chem. Soc. 2010, 132, 6057-6067. [CrossRef] [PubMed]

18. Alessandra, P.; Cinzia, P.; Paola, G.; Vincenza, F.; Sannia, G. Heterologous laccase production and its role in industrial applications. Bioeng. Bugs 2010, 1, 252-262.

19. Kudanga, T.; Nemadziva, B.; Le Roes-Hill, M. Laccase catalysis for the synthesis of bioactive compounds. Appl. Microbiol. Biotechnol. 2017, 101, 13-33. [CrossRef] [PubMed]

20. Ba, S.; Vinoth Kumar, V. Recent developments in the use of tyrosinase and laccase in environmental applications. Crit. Rev. Biotechnol. 2017, 37, 819-832. [CrossRef] [PubMed]

21. Viswanath, B.; Rajesh, B.; Janardhan, A.; Kumar, A.P.; Narasimha, G. Fungal laccases and their applications in bioremediation. Enzym. Res. 2014, 2014, 163242. [CrossRef] [PubMed]

22. Rodríguez Couto, S.; Toca Herrera, J.L. Industrial and biotechnological applications of laccases: A review. Biotechnol. Adv. 2006, 24, 500-513. [CrossRef] [PubMed]

23. Riva, S. Laccases: Blue enzymes for green chemistry. Trends Biotechnol. 2006, 24, 219-226. [CrossRef] [PubMed]

24. Morozova, O.V.; Shumakovich, G.P.; Gorbacheva, M.A.; Shleev, S.V.; Yaropolov, A.I. "Blue" laccases. Biochemistry 2007, 72, 1136-1150. [CrossRef] [PubMed]

25. Brijwani, K.; Rigdon, A.; Vadlani, P.V. Fungal laccases: Production, function, and applications in food processing. Enzym. Res. 2010, 2010, 149748. [CrossRef] [PubMed] 
26. Kurniawati, S.; Nicell, J.A. A comprehensive kinetic model of laccase-catalyzed oxidation of aqueous phenol. Biotechnol. Prog. 2009, 25, 763-773. [CrossRef] [PubMed]

27. Anastas, P.T.; Warner, J.C. Green Chemistry Theory and Practice, 1st ed.; Oxford University Press: Oxford, UK, 2000; p. 152. ISBN 978-0198506980.

28. Perveen, S.; Al-Taweel, A.M. Green Chemistry and Synthesis of Anticancer Molecule. In Green Chemistry; El-Din, H., Saleh, M., Eds.; IntechOpen: London, UK, 2018; Volume 1, pp. 51-72. ISBN 978-953-51-3848-8.

29. Bourbonnais, R.; Paice, M.G. Oxidation of non-phenolic substrates. FEBS Lett. 1990, 267, 99-102. [CrossRef]

30. Wellington, K.W.; Kolesnikova, N.I. A laccase-catalysed one-pot synthesis of aminonaphthoquinones and their anticancer activity. Bioorg. Med. Chem. 2012, 20, 4472-4481. [CrossRef] [PubMed]

31. Wellington, K.W.; Bokako, R.; Raseroka, N.; Steenkamp, P. A one-pot synthesis of 1,4-naphthoquinone-2,3-bis-sulfides catalysed by a commercial laccase. Green Chem. 2012, 14, 2567-2576. [CrossRef]

32. Wellington, K.W.; Qwebani-Ogunleye, T.; Kolesnikova, N.I.; Brady, D.; de Koning, C.B. One-pot laccase-catalysed synthesis of 5,6-dihydroxylated benzo[b]furans and catechol derivatives, and their anticancer activity. Arch. Pharm. 2013, 346, 266-277. [CrossRef] [PubMed]

33. Qwebani-Ogunleye, T.; Kolesnikova, N.I.; Steenkamp, P.; de Koning, C.B.; Brady, D.; Wellington, K.W. A one-pot laccase-catalysed synthesis of coumestan derivatives and their anticancer activity. Bioorg. Med. Chem. 2017, 25, 1172-1182. [CrossRef] [PubMed]

34. Abdel-Mohsen, H.T.; Conrad, J.; Harms, K.; Nohr, D.; Beifuss, U. Laccase-catalyzed green synthesis and cytotoxic activity of novel pyrimidobenzothiazoles and catechol thioethers. RSC Adv. 2017, 7, 17427-17441. [CrossRef]

35. Jadhav, S.B.; Singhal, R.S. Laccase-gum Arabic conjugate for preparation of water-soluble oligomer of catechin with enhanced antioxidant activity. Food Chem. 2014, 150, 9-16. [CrossRef] [PubMed]

36. Chebil, L.; Rhouma, G.; Chekir-Ghedira, L.; Ghoul, M. Enzymatic Polymerization of Rutin and Esculin and Evaluation of the Antioxidant Capacity of Polyrutin and Polyesculin. In Biotechnology; Ekinci, D., Ed.; IntechOpen Lomited: London, UK, 2015; Volume 1, ISBN 978-953-51-2040-7.

37. Ezgi Ünlü, A.; Prasad, B.; Anavekar, K.; Bubenheim, P.; Liese, A. Investigation of a green process for the polymerization of catechin. Prep. Biochem. Biotechnol. 2017, 47, 918-924. [CrossRef] [PubMed]

38. Abdel-Mohsen, H.T.; Conrad, J.; Beifuss, U. Laccase-catalyzed synthesis of catechol thioethers by reaction of catechols with thiols using air as an oxidant. Green Chem. 2014, 16, 90-95. [CrossRef]

39. Mikolasch, A.; Manda, K.; Schlüter, R.; Lalk, M.; Witt, S.; Seefeldt, S.; Hammer, E.; Schauer, F.; Jülich, W.D.; Lindequist, U. Comparative analyses of laccase-catalyzed amination reactions for production of novel $\beta$-lactam antibiotics. Biotechnol. Appl. Biochem. 2012, 59, 295-306. [CrossRef] [PubMed]

40. Abdel-Mohsen, H.T.; Conrad, J.; Beifuss, U. Laccase-Catalyzed Domino Reaction between Catechols and 6-Substituted 1,2,3,4-Tetrahydro-4-oxo-2-thioxo-5-pyrimidinecarbonitriles for the Synthesis of Pyrimidobenzothiazole Derivatives. J. Org. Chem. 2013, 78, 7986-8003. [CrossRef] [PubMed]

41. Jeon, S.-Y.; Oh, S.; Kim, E.; Imm, J.-Y. $\alpha$-Glucosidase Inhibiton and Antiglycation Activity of Laccase-Catalyzed Catechin Polymers. J. Agric. Food Chem. 2013, 61, 4577-4584. [CrossRef] [PubMed]

42. Kidwai, M.; Jain, A.; Sharma, A.; Kuhad, R.C. Laccase-catalysed reaction between Meldrum's acid and catechols/hydroquinones-An investigation. C. R. Chim. 2013, 16, 728-735. [CrossRef]

43. Cannatelli, M.D.; Ragauskas, A.J. Laccase-catalyzed $\alpha$-arylation of benzoylacetonitrile with substituted hydroquinones. Chem. Eng. Res. Des. 2015, 97, 128-134. [CrossRef]

44. Cannatelli, M.D.; Ragauskas, A.J. Ecofriendly syntheses of phenothiazones and related structures facilitated by laccase-A comparative study. Tetrahedron Lett. 2016, 57, 3749-3753. [CrossRef]

45. Hahn, V.; Mikolasch, A.; Kuhlisch, C.; Schauer, F. Laccase-mediated multi-step homo- and heteromolecular reactions of ortho-dihydroxylated aromatic compounds and mono- or diaminated substances resulting in CC, CO and CN bonds. J. Mol. Catal. B Enzym. 2015, 122, 56-63. [CrossRef]

46. Habibi, D.; Rahimi, A.; Rostami, A.; Moradi, S. Green and mild laccase-catalyzed aerobic oxidative coupling of benzenediol derivatives with various sodium benzenesulfinates. Tetrahedron Lett. 2017, 58, 289-293. [CrossRef]

47. Kidwai, M.; Jain, A.; Sharma, A.; Kuhad, R.C. First time reported enzymatic synthesis of new series of quinoxalines-A green approach. J. Mol. Catal. B Enzym. 2012, 74, 236-240. [CrossRef] 
48. Antibiotic Resistance. Available online: http://www.who.int/mediacentre/factsheets/antibiotic-resistance/ en/ (accessed on 30 April 2018).

49. Hajdok, S.; Leutbecher, H.; Greiner, G.; Conrad, J.; Beifuss, U. Laccase initiated oxidative domino reactions for the efficient synthesis of 3,4-dihydro-7,8-dihydroxy-2H-dibenzofuran-1-ones. Tetrahedron Lett. 2007, 48, 5073-5076. [CrossRef]

50. Leutbecher, H.; Conrad, J.; Klaiber, I.; Beifuss, U. O-Heterocycles via Laccase-Catalyzed Domino Reactions with $\mathrm{O}_{2}$ as the Oxidant. Synlett 2005, 20,3126-3130. [CrossRef]

51. Bhalerao, U.T.; Muralikrishna, C.; Pandey, G. An Efficient Synthesis of Coumestans-A Probable Biogenetic Approach. Synth. Commun. 1989, 19, 1303-1307. [CrossRef]

52. Nematollahi, D.; Habibi, D.; Rahmati, M.; Rafiee, M. A Facile Electrochemical Method for Synthesis of New Benzofuran Derivatives. J. Org. Chem. 2004, 69, 2637-2640. [CrossRef] [PubMed]

53. Tabaković, I.; Grujić, Z.; Bejtović, Z. Electrochemical synthesis of heterocyclic compounds. XII. Anodic oxidation of catechol in the presence of nucleophiles. J. Heterocycl. Chem. 1983, 20, 635-638. [CrossRef]

54. Pandey, K.B.; Rizvi, S.I. Plant polyphenols as dietary antioxidants in human health and disease. Oxid. Med. Cell. Longev. 2009, 2, 270-278. [CrossRef] [PubMed]

55. Jeon, J.R.; Baldrian, P.; Murugesan, K.; Chang, Y.S. Laccase-catalysed oxidations of naturally occurring phenols: From in vivo biosynthetic pathways to green synthetic applications. Microb. Biotechnol. 2012, 5, 318-332. [CrossRef] [PubMed]

56. Kurisawa, M.; Chung, J.E.; Uyama, H.; Kobayashi, S. Enzymatic Synthesis and Antioxidant Properties of Poly(rutin). Biomacromolecules 2003, 4, 1394-1399. [CrossRef] [PubMed]

57. Desentis-Mendoza, R.M.; Hernández-Sánchez, H.; Moreno, A.; Rojas del c, E.; Chel-Guerrero, L.; Tamariz, J.; Jaramillo-Flores, M.E. Enzymatic Polymerization of Phenolic Compounds Using Laccase and Tyrosinase from Ustilago maydis. Biomacromolecules 2006, 7, 1845-1854. [CrossRef] [PubMed]

58. Draenert, R.; Seybold, U.; Grützner, E.; Bogner, J.R. Novel antibiotics: Are we still in the pre-post-antibiotic era? Infection 2015, 43, 145-151. [CrossRef] [PubMed]

59. Aminov, R.I. A Brief History of the Antibiotic Era: Lessons Learned and Challenges for the Future. Front. Microbiol. 2010, 1, 134. [CrossRef] [PubMed]

60. Agematu, H.; Tshuchida, T.; Kominato, K.; Shibamoto, N.; Yoshioka, T.; Nishida, H.; Okamoto, R. Enzymatic dimerization of penicillin X. J. Antibiot. 1993, 46, 141-148. [CrossRef] [PubMed]

61. Wild, S.; Roglic, G.; Green, A.; Sicree, R.; King, H. Global prevalence of diabetes. Estimates for the year 2000 and projections for 2030. Diabetes Care 2004, 27, 1047-1053. [CrossRef] [PubMed]

62. Antošová, Z.; Sychrová, H. Yeast Hosts for the Production of Recombinant Laccases: A Review. Mol. Biotechnol. 2016, 58, 93-116. [CrossRef] [PubMed]

63. Ba, S.; Arsenault, A.; Hassani, T.; Jones, J.P.; Cabana, H. Laccase immobilization and insolubilization: From fundamentals to applications for the elimination of emerging contaminants in wastewater treatment. Crit. Rev. Biotechnol. 2013, 33, 404-418. [CrossRef] [PubMed]

64. Bertrand, B.; Martínez-Morales, F.; Trejo-Hernández, M.R. Upgrading Laccase Production and Biochemical Properties: Strategies and Challenges. Biotechnol. Prog. 2017, 33, 1015-1034. [CrossRef] [PubMed]

65. Upadhyay, P.; Shrivastava, R.; Agrawal, P.K. Bioprospecting and biotechnological applications of fungal laccase. 3 Biotech. 2016, 6, 15. [CrossRef] [PubMed]

66. Yang, J.; Li, W.; Bun Ng, T.; Deng, X.; Lin, J.; Ye, X. Laccases: Production, expression regulation, and applications in pharmaceutical biodegradation. Front. Microbiol. 2017, 8, 832. [CrossRef] [PubMed]

67. Tinoco-Valencia, R.; Gómez-Cruz, C.; Galindo, E.; Serrano-Carreón, L. Toward an understanding of the effects of agitation and aeration on growth and laccases production by Pleurotus ostreatus. J. Biotechnol. 2014, 177, 67-73. [CrossRef] [PubMed]

68. Revankar, M.S.; Lele, S.S. Enhanced production of laccase using a new isolate of white rot fungus WR-1. Process. Biochem. 2006, 41, 581-588. [CrossRef]

69. Wang, S.S.; Ning, Y.J.; Wang, S.N.; Zhang, J.; Zhang, G.Q.; Chen, Q.J. Purification, characterization, and cloning of an extracellular laccase with potent dye decolorizing ability from white rot fungus Cerrena unicolor GSM-01. Int. J. Biol. Macromol. 2017, 95, 920-927. [CrossRef] [PubMed]

70. Sondhi, S.; Sharma, P.; George, N.; Chauhan, P.S.; Puri, N.; Gupta, N. An extracellular thermo-alkali-stable laccase from Bacillus tequilensis SN4, with a potential to biobleach softwood pulp. 3 Biotech. 2015, 5, 175-185. [CrossRef] [PubMed] 
71. Ausec, L.; Berini, F.; Casciello, C.; Cretoiu, M.S.; van Elsas, J.D.; Marinelli, F.; Mandic-Mulec, I. The first acidobacterial laccase-like multicopper oxidase revealed by metagenomics shows high salt and thermo-tolerance. Appl. Microbiol. Biotechnol. 2017, 101, 6261-6276. [CrossRef] [PubMed]

72. Martins, L.O.; Durão, P.; Brissos, V.; Lindley, P.F. Laccases of prokaryotic origin: Enzymes at the interface of protein science and protein technology. Cell. Mol. Life Sci. 2015, 72, 911-922. [CrossRef] [PubMed]

73. Ma, X.; Liu, L.; Li, Q.; Liu, Y.; Yi, L.; Ma, L.; Zhai, C. High-level expression of a bacterial laccase, CueO from Escherichia coli K12 in Pichia pastoris GS115 and its application on the decolorization of synthetic dyes. Enzym. Microb. Technol. 2017, 103, 34-41. [CrossRef] [PubMed]

74. Tonin, F.; Melis, R.; Cordes, A.; Sanchez-Amat, A.; Pollegioni, L.; Rosini, E. Comparison of different microbial laccases as tools for industrial uses. New Biotechnol. 2016, 33, 387-398. [CrossRef] [PubMed]

75. Pezzella, C.; Giacobelli, V.G.; Lettera, V.; Olivieri, G.; Cicatiello, P.; Sannia, G.; Piscitelli, A. A step forward in laccase exploitation: Recombinant production and evaluation of techno-economic feasibility of the process. J. Biotechnol. 2017, 259, 175-181. [CrossRef] [PubMed]

76. Mate, D.M.; Alcalde, M. Laccase engineering: From rational design to directed evolution. Biotechnol. Adv. 2015, 33, 25-40. [CrossRef] [PubMed]

77. Ihssen, J.; Reiss, R.; Luchsinger, R.; Thöny-Meyer, L.; Richter, M. Biochemical properties and yields of diverse bacterial laccase-like multicopper oxidases expressed in Escherichia coli. Sci. Rep. 2015, 5, 10465. [CrossRef] [PubMed]

78. Arimoto, M.; Yamagishi, K.; Wang, J.; Tanaka, K.; Miyoshi, T.; Kamei, I.; Kondo, R.; Mori, T.; Kawagishi, H.; Hirai, H. Molecular breeding of lignin-degrading brown-rot fungus Gloeophyllum trabeum by homologous expression of laccase gene. AMB Express 2015, 5, 81. [CrossRef] [PubMed]

79. Ryu, S.H.; Cho, M.K.; Kim, M.; Jung, S.M.; Seo, J.H. Enhanced lignin biodegradation by a laccase-overexpressed white-rot fungus polyporus brumalis in the pretreatment of wood chips. Appl. Biochem. Biotechnol. 2013, 171, 1525-1534. [CrossRef] [PubMed]

80. Jiao, X.; Li, G.; Wang, Y.; Nie, F.; Cheng, X.; Abdullah, M.; Lin, Y.; Cai, Y. Systematic Analysis of the Pleurotus ostreatus Laccase Gene (PoLac) Family and Functional Characterization of PoLac2 Involved in the Degradation of Cotton-Straw Lignin. Molecules 2018, 23, 880. [CrossRef] [PubMed]

81. Songulashvili, G.; Jimenéz-Tobón, G.A.; Jaspers, C.; Penninckx, M.J. Immobilized laccase of Cerrena unicolor for elimination of endocrine disruptor micropollutants. Fungal Biol. 2012, 116, 883-889. [CrossRef] [PubMed]

82. Songulashvili, G.; Spindler, D.; Jimenéz-Tobón, G.A.; Jaspers, C.; Kerns, G.; Penninckx, M.J. Production of a high level of laccase by submerged fermentation at 120-L scale of Cerrena unicolor C-139 grown on wheat bran. C. R. Biol. 2015, 338, 121-125. [CrossRef] [PubMed]

83. Yang, J.; Wang, G.; Ng, T.B.; Lin, J.; Ye, X. Laccase production and differential transcription of laccase genes in Cerrena sp. in response to metal ions, aromatic compounds, and nutrients. Front. Microbiol. 2016, 6, 1558. [CrossRef] [PubMed]

84. Chen, S.C.; Wu, P.H.; Su, Y.C.; Wen, T.N.; Wei, Y.S.; Wang, N.C.; Hsu, C.A.; Wang, A.H.J.; Shyur, L.F. Biochemical characterization of a novel laccase from the basidiomycete fungus Cerrena sp. WR1. Protein Eng. Des. Sel. 2012, 25, 761-769. [CrossRef] [PubMed]

85. Songulashvili, G.; Flahaut, S.; Demarez, M.; Tricot, C.; Bauvois, C.; Debaste, F.; Penninckx, M.J. High yield production in seven days of Coriolopsis gallica 1184 laccase at $50 \mathrm{~L}$ scale; enzyme purification and molecular characterization. Fungal Biol. 2016, 120, 481-488. [CrossRef] [PubMed]

86. Galhaup, C.; Wagner, H.; Hinterstoisser, B.; Haltrich, D. Increased production of laccase by the wood-degrading basidiomycete Trametes pubescens. Enzym. Microb. Technol. 2002, 30, 529-536. [CrossRef]

87. Afreen, S.; Anwer, R.; Singh, R.K.; Fatma, T. Extracellular laccase production and its optimization from Arthrospira maxima catalyzed decolorization of synthetic dyes. Saudi J. Biol. Sci. 2016. [CrossRef]

88. Kumar, D.; Kumar, A.; Sondhi, S.; Sharma, P.; Gupta, N. An alkaline bacterial laccase for polymerization of natural precursors for hair dye synthesis. 3 Biotech. 2018, 8, 1-10. [CrossRef] [PubMed]

89. Mekmouche, Y.; Zhou, S.; Cusano, A.M.; Record, E.; Lomascolo, A.; Robert, V.; Simaan, A.J.; Rousselot-Pailley, P.; Ullah, S.; Chaspoul, F.; et al. Gram-scale production of a basidiomycetous laccase in Aspergillus niger. J. Biosci. Bioeng. 2014, 117, 25-27. [CrossRef] [PubMed]

90. Nishibori, N.; Masaki, K.; Tsuchioka, H.; Fujii, T.; Iefuji, H. Comparison of laccase production levels in pichia pastoris and Cryptococcus sp. S-2. J. Biosci. Bioeng. 2013, 115, 394-399. [CrossRef] [PubMed] 
91. Yang, J.; Ng, T.B.; Lin, J.; Ye, X. A novel laccase from basidiomycete Cerrena sp.: Cloning, heterologous expression, and characterization. Int. J. Biol. Macromol. 2015, 77, 344-349. [CrossRef] [PubMed]

92. Macellaro, G.; Baratto, M.C.; Piscitelli, A.; Pezzella, C.; Fabrizi De Biani, F.; Palmese, A.; Piumi, F.; Record, E.; Basosi, R.; Sannia, G. Effective mutations in a high redox potential laccase from Pleurotus ostreatus. Appl. Microbiol. Biotechnol. 2014, 98, 4949-4961. [CrossRef] [PubMed]

93. Zhou, H.M.; Hong, Y.Z.; Xiao, Y.Z.; Cui, T.J.; Wang, X.T.; Pu, C.L. High Output of a Trametes Laccase in Pichia pastoris and Characterization of Recombinant Enzymes. Chin. J. Biotechnol. 2007, 23, 1055-1059. [CrossRef]

94. Li, Q.; Ge, L.; Cai, J.; Pei, J.; Xie, J.; Zhao, L. Comparison of two laccases from Trametes versicolor for application in the decolorization of dyes. J. Microbiol. Biotechnol. 2014, 24, 545-555. [CrossRef] [PubMed]

95. Samak, N.A.; Hu, J.; Wang, K.; Guo, C.; Liu, C. Development of a Novel Micro-Aerobic Cultivation Strategy for High Potential CotA Laccase Production. Waste Biomass Valorization 2018, 9, 369-377. [CrossRef]

96. Ihssen, J.; Schubert, M.; Thöny-Meyer, L.; Richter, M. Laccase catalyzed synthesis of iodinated phenolic compounds with antifungal activity. PLoS ONE. 2014, 9, e89924. [CrossRef] [PubMed]

97. Zdarta, J.; Meyer, A.; Jesionowski, T.; Pinelo, M. A General Overview of Support Materials for Enzyme Immobilization: Characteristics, Properties, Practical Utility. Catalysts 2018, 8, 92. [CrossRef]

98. Spahn, C.; Minteer, S.D. Enzyme Immobilization in Biotechnology. Recent Pat. Eng. 2008, 2, $195-200$. [CrossRef]

99. Aguila, S.; Vazquez-Duhalt, R.; Covarrubias, C.; Pecchi, G.; Alderete, J.B. Enhancing oxidation activity and stability of iso-1-cytochrome $\mathrm{c}$ and chloroperoxidase by immobilization in nanostructured supports. J. Mol. Catal. B Enzym. 2011, 70, 81-87. [CrossRef]

100. Campos-Terán, J.; Iñarritu, I.; Aburto, J.; Torres, E. Enhanced Functionality of Peroxidases by Its Immobilization at the Solid-Liquid Interface of Mesoporous Materials and Nanoparticles. In Proteins in Solution and at Interfaces; John Wiley \& Sons, Inc.: Hoboken, NJ, USA, 2013; pp. 335-351. ISBN 9781118523063.

101. Kumar, V.V.; Cabana, H. Towards high potential magnetic biocatalysts for on-demand elimination of pharmaceuticals. Bioresour. Technol. 2016, 200, 81-89. [CrossRef] [PubMed]

102. Rouhani, S.; Rostami, A.; Salimi, A.; Pourshiani, O. Graphene oxide $/ \mathrm{CuFe}{ }_{2} \mathrm{O}_{4}$ nanocomposite as a novel scaffold for the immobilization of laccase and its application as a recyclable nanobiocatalyst for the green synthesis of arylsulfonyl benzenediols. Biochem. Eng. J. 2018, 133, 1-11. [CrossRef]

103. Alver, E.; Metin, A.Ü. Chitosan based metal-chelated copolymer nanoparticles: Laccase immobilization and phenol degradation studies. Int. Biodeterior. Biodegrad. 2017, 125, 235-242. [CrossRef]

104. Taheran, M.; Naghdi, M.; Brar, S.K.; Knystautas, E.J.; Verma, M.; Surampalli, R.Y. Degradation of chlortetracycline using immobilized laccase on Polyacrylonitrile-biochar composite nanofibrous membrane. Sci. Total Environ. 2017, 605-606, 315-321. [CrossRef] [PubMed]

105. Hommes, G.; Gasser, C.A.; Howald, C.B.C.; Goers, R.; Schlosser, D.; Shahgaldian, P.; Corvini, P.F.X. Production of a robust nanobiocatalyst for municipal wastewater treatment. Bioresour. Technol. 2012, 115, 8-15. [CrossRef] [PubMed]

106. Nguyen, L.N.; Hai, F.I.; Dosseto, A.; Richardson, C.; Price, W.E.; Nghiem, L.D. Continuous adsorption and biotransformation of micropollutants by granular activated carbon-bound laccase in a packed-bed enzyme reactor. Bioresour. Technol. 2016, 210, 108-116. [CrossRef] [PubMed]

107. Chen, Y.; Stemple, B.; Kumar, M.; Wei, N. Cell Surface Display Fungal Laccase as a Renewable Biocatalyst for Degradation of Persistent Micropollutants Bisphenol A and Sulfamethoxazole. Environ. Sci. Technol. 2016, 50, 8799-8808. [CrossRef] [PubMed]

108. Patel, S.K.S.; Otari, S.V.; Li, J.; Kim, D.R.; Kim, S.C.; Cho, B.-K.; Kalia, V.C.; Kang, Y.C.; Lee, J.-K. Synthesis of cross-linked protein-metal hybrid nanoflowers and its application in repeated batch decolorization of synthetic dyes. J. Hazard. Mater. 2018, 347, 442-450. [CrossRef] [PubMed]

109. Ma, H.-F.; Meng, G.; Cui, B.-K.; Si, J.; Dai, Y.-C. Chitosan crosslinked with genipin as supporting matrix for biodegradation of synthetic dyes: Laccase immobilization and characterization. Chem. Eng. Res. Des. 2018, 132, 664-676. [CrossRef]

110. Taheran, M.; Naghdi, M.; Brar, S.K.; Knystautas, E.J.; Verma, M.; Surampalli, R.Y. Covalent Immobilization of Laccase onto Nanofibrous Membrane for Degradation of Pharmaceutical Residues in Water. ACS Sustain. Chem. Eng. 2017, 5, 10430-10438. [CrossRef] 
111. Arca-Ramos, A.; Kumar, V.V.; Eibes, G.; Moreira, M.T.; Cabana, H. Recyclable cross-linked laccase aggregates coupled to magnetic silica microbeads for elimination of pharmaceuticals from municipal wastewater. Environ. Sci. Pollut. Res. 2016, 23, 8929-8939. [CrossRef] [PubMed]

112. Rahmani, K.; Faramarzi, M.A.; Mahvi, A.H.; Gholami, M.; Esrafili, A.; Forootanfar, H.; Farzadkia, M. Elimination and detoxification of sulfathiazole and sulfamethoxazole assisted by laccase immobilized on porous silica beads. Int. Biodeterior. Biodegrad. 2015, 97, 107-114. [CrossRef]

113. De Cazes, M.; Belleville, M.P.; Petit, E.; Llorca, M.; Rodríguez-Mozaz, S.; de Gunzburg, J.; Barceló, D.; Sanchez-Marcano, J. Design and optimization of an enzymatic membrane reactor for tetracycline degradation. Catal. Today 2014, 236, 146-152. [CrossRef]

(C) 2018 by the authors. Licensee MDPI, Basel, Switzerland. This article is an open access article distributed under the terms and conditions of the Creative Commons Attribution (CC BY) license (http://creativecommons.org/licenses/by/4.0/). 